\title{
Facets of Focalisation and Ideology in the Stream-of Consciousness Mode: A Study of Lawrence Darmani's Grief Child.
}

\author{
Yémalo, C. AMOUSSOU* \\ FLLAC/UAC, Benin Republic; West Africa.
}

*Corresponding Author: Yémalo, C. AMOUSSOU, FLLAC/UAC, Benin Republic; West Africa.

\begin{abstract}
This paper explores the distinctive features of the stream-of-consciousness mode in Darmani's first novel Grief Child with a view to uncovering the ideological inclination of the main focaliser and the narrator and/or the writer. It draws on the process-type taxonomy proposed by Halliday and Matthiessen (2004) to analyse three dream-depicting extracts and comes to the conclusion that the outer-experience processes that are generally held to hold the lion's share in transitivity analyses are suspended in this mode of discourse while those of inner experience occur dominantly. Not only does this result in the dominance of the cognitive and psychological facets of focalisation over the perceptual and ideological ones, but it also helps the writer/narrator to use the spiritual life of the characters as the determinant of the physical one.
\end{abstract}

Keywords: stream of consciousness, facet of focalisation, mental process, rewriteable discourse, ideology.

\section{INTRODUCTION}

While it is strongly argued that a study of literature without regard to its peculiarities would be meaningless (Amoussou, 2014: 120, 132-32; 2017: 263; Jakobson, 1960: 377; Culler, 1975:114; Widdowson, 1975:3; 14; Littlewood, 1976: 22; Brumfit \& Carter, 1991: 8; etc); many linguisticsoriented analyses of fiction still disregard the impact of narrative artifacts like the modes of narration and focalisation on the distribution of the ideational, textual and interpersonal features of literary texts (Halliday, 1970:67). Indeed, just as a writer's approach to character (external or internal) can influence the distribution of Process and Participant functions in narratives, the same can affect their Theme patterns and distribution on the one hand and their Mood structure and distribution on the other.

This study investigates the stream-of-consciousness mode from the experiential meaning perspective. It focuses on the distribution of transitivity features in three samples from the novel Grief Child (Darmani, 1991) to uncover how the distribution of process-types reflects not only the features of this mode but also reveals the ideological orientation of the major narrative agents. It is deemed necessary to overview the conceptual, theoretical and methodological framework before the analysis and interpretation of findings.

\section{Conceptual, Theoretical And Methodological Framework}

The phrasing of this research topic requires the clarification of such conceptual notions as 'stream of consciousness' and 'facets of focalisation' and of other theoretical ones like transitivity, experiential meaning and process-types.

\subsection{Conceptual Definitions and Clarifications}

The phrase 'stream of consciousness' is reported to have been coined by James (1890: 243) and defined as follows:

Consciousness, then, does not appear to itself as chopped up in bits ... it is nothing joined; it flows. A 'river' or a 'stream' are the metaphors by which it is most naturally described. In talking of it hereafter, let's call it the stream of thought, consciousness, or subjective life" (Stevenson, 1992: 39)

Basically, it is 'a narrative mode or method that attempts to depict the multitudinous thoughts and feelings which pass through the mind' (Cuddon, 1984: 660-61). Likewise Childs \& Fowler 
Facets of Focalisation and Ideology in the Stream-of Consciousness Mode: A Study of Lawrence Darmani's Grief Child.

(2006:224) see it as "a technique which seeks to record the flow of impressions passing through a character's mind." It thus becomes difficult to discuss the 'stream of consciousness' without alluding to its twin concept: the interior monologue. Murfin and Ray (2003:199) establish some hyponymic relationship between the two in writing:

Although 'stream of consciousness' and 'interior monologue' are often used interchangeably, the former is the more general term. Interior monologue, strictly defined, is a type of stream of consciousness. As such, it presents a character's thoughts, emotions, and fleeting sensations to the reader. Unlike stream of consciousness more generally, however, the ebb and flow of the psyche revealed by interior monologue typically exists at a pre-or sub linguistic level, where images and the connotations they evoke supplant the literal denotative meanings of words.

Likewise, Baldick (2009: 212) acknowledges the substitution between the two terms, and goes a step further to specify their double-disciplinary usage and differential focus:

They can also be distinguished psychologically and literarily. 'In a psychological sense, stream of consciousness is the subject- matter, while interior monologue is the technique for presenting it'. And for literature, 'while an interior monologue always presents a character's thoughts 'directly', without the apparent intervention of a summarizing and selecting narrator, it does not necessarily mingle them with impressions and perceptions, nor does it necessarily violate the norms of grammar, or logic- but the stream- of- consciousness technique also does one or both of these things'.

While the difference thus lies in the form (direct or indirect) of the presentation of the character's thoughts, the acknowledgement that the stream of consciousness can be rendered in both forms makes the distinction even foggier. However, Dujardin (1931: 59), a pioneer in the use of the interior monologue technique, defines it, in a way that makes it carry the same semantic import as the JamesStevenson one earlier examined, as:

a discourse without an auditor and unspoken, by which a character expresses his most intimate thoughts, those closest to the unconscious, prior to all logical organization, or, simply, thought in its dawning state -expresses it by means of direct phrases reduced to their syntactical minimum, in such a way as to give the impression a hodgepodge.

This definition applies more strictly to the 'direct monologue', in which a character thinks or talks to themselves, as opposed to what Cohn (1966) calls 'indirect/narrated monologue', i.e., the technique of internal depiction of a character's thoughts by the use of the third-person pronoun and the tense of narration. In other words, in the case of direct interior monologue, the author/narrator seems to be absent and the character's interior self is revealed directly, as if the reader were overhearing an articulation of thoughts and feelings flowing through the character's mind-window. In the indirect one, narrator serves as the selector, presenter, guide, and commentator of the character's impressions (Uspensky, 1973:75). In the latter case, the narrator's intrusion is felt on through the use of free indirect discourse devices and modality, which requires careful reading to tell the narrator's participation from a character's. That is why Barthes (1975: 262) suggests a test to see whether a narrated discourse string is internally focalized or not: when a string that is not initially in the first person can be rewritten into that person without the need for "any alteration of the discourse other than the change in grammatical pronouns (and tenses)", then it is internally focalized but when it cannot, then it is externally focalized.

Drawing on Uspensky (1973:75), Rimmon-Kenan (1983: 81) lists some experiential and interpersonal indicators of the internally-focalized discourse:

When the focalized is seen from within, especially by an external focaliser, indicators such as 'he thought', 'he felt', 'it seemed to him', 'he knew', 'he recognized' often appear in the text. On the other hand, when the inner states of the focalized are left to be implied by external behaviour, modal expressions - suggesting the speculative status of such implication -often occur: 'apparently', evidently, 'as if', 'it seemed', etc. Uspensky calls these 'words of estrangement' (1973:p.75) (my bolding \&italics).

While the highlighted verbs in the quote above belong to the group known as 'mental processes,' 'the external-behaviour-signals' have to do with 'behavioural processes' and the modal locutions are part 
Facets of Focalisation and Ideology in the Stream-of Consciousness Mode: A Study of Lawrence Darmani's Grief Child.

of 'modalisers/estrangers.' It thus comes out that 'a stream of consciousness-dominated discourse' or 'internally-focalized discourse' (Barthes, 1975: 262) is most likely to rely on mental and behavioural processes with the intrusion of an observing narrator/character through the use of Uspensky's 'words of estrangement'. Indeed, these are the major indicators of the stream of consciousness, which Fowler (1986: 137) sees as a "directly experienced mental process".

Indeed the use of such words as 'mind' and 'thought' in most definitions of the stream of consciousness (Baldick, 2009: 212; Childs \& Fowler, 2006:224; Stevenson, 1992: 39) and of such others as 'vision/to see' in those of 'focalisation/focaliser' (Genette, 1980: 186; Fowler; 1986: 134) tends to limit the scope of the stream of thought to 'thinking' and of focalisation to 'seeing'. In practice, though, the word 'mind/vision' should be broadened to encompass what systemic functional linguists call 'processes of inner experience' or 'mental processes,' which includes four aspects: perception, cognition, desideration and affection (Halliday \& Matthiessen, 2004: 170, 208; Amoussou, 2016: 249). To these, behavioural processes, which 'represent the outer manifestations or the acting out of processes of consciousness and psychological states' (Halliday \&Matthiessen, 2004:171; 251), must be added, as such aspects as dreams, daydreams, visions, memories, internal voices, etc are vehicles of the stream of consciousness.

\subsection{Theoretical and Methodological Considerations}

It emerges from the conceptual background that the 'stream of consciousness' is related to the perception, the flow and representation of narrative experience (Fowler, 1986: 134; Genette, 1980: 186). As the domain of experience is construed through the experiential grammar or Transitivity (Eggins, 1994:99; Halliday \& Matthiessen, 2004: 170), which involves the analysis of Processes, Participants and Circumstances, this study draws on the taxonomy proposed by Eggins (2004:215248) and Halliday \& Matthiessen (2004:170-260) to analyze the Processes but overlooks Participants and Circumstances, these mattering little for its purpose. Those scholars distinguish six major processtypes $(P T)$, some of which are broken into sub-types and initialized as follows: (1) material processes: transitive material processes $(T M P)+$ middle material processes $(M M P) ;(2)$ meteorological processes $(M T P)$; (3) mental processes $(M e P)$ : perceptive $(M e P-P)+$ cognitive $(\mathrm{MeP}-\mathrm{C})+$ emotive $(M e P-E)+$ desiderative $(M e P-D)$; (4) behavioural processes $(B P)$; $(5)$ relational processes $(R P)$ : attributive $(A R P)+$ identifying $(I R P)+$ circumstantial $(C R P)+$ possessive $(P R P)+$ existential $(E R P)$, and $(6)$ verbal processes $(V P)$. These are defined, drawing on Halliday and Matthiessen (2004: 170, 171, 257, and 258), exemplified and illustrated in the table below:

Table1. Process-Taxonomy-defintions-illustrations, inspired from Halliday\& Matthiessen, 2004: 170-71; 2578)

\begin{tabular}{|c|c|c|c|}
\hline \multicolumn{2}{|l|}{$P T$} & Definitions and examples & Example sentences \\
\hline \multirow[t]{2}{*}{$M P$} & $T M P$ & $\begin{array}{l}\text {-a process of the external world with an actor } \\
\text { impacting on a goal: to eat, to kill, to knock, etc }\end{array}$ & $\begin{array}{l}\text { e.g.: -Paul killed the snake with a stick. } \\
\text {-Nell knocked him on the first round. }\end{array}$ \\
\hline & $M M P$ & $\begin{array}{l}\text {-a process of the outer world with an actor in a } \\
\text { movement action: to go, to run, to jump, etc }\end{array}$ & $\begin{array}{l}\text { e.g.: -Ben ran as fast as possible. } \\
\text { - Tasso played very well yesterday. }\end{array}$ \\
\hline \multicolumn{2}{|l|}{$M T P$} & $\begin{array}{l}\text { - 'a process that deals with the weather': to rain, } \\
\text { to snow, to breeze }\end{array}$ & $\begin{array}{l}\text { - e.g.: -The wind blew wildly. } \\
\text { - It was very foggy yesterday. }\end{array}$ \\
\hline \multirow[t]{4}{*}{$\mathrm{MeP}$} & $(P)$ & $\begin{array}{l}\text {-a process the inner world showing perception: } \\
\text { to see, to hear, to feel, to taste, etc }\end{array}$ & $\begin{array}{l}\text {-e.g.: -Bello heard the news on the radio. } \\
\text { - Sarah saw the boy from a distance. }\end{array}$ \\
\hline & $\begin{array}{l}(- \\
C)\end{array}$ & $\begin{array}{l}\text {-a process of the inner world expressing } \\
\text { cognition: to think, to know, to remember, etc. }\end{array}$ & $\begin{array}{l}\text { - e.g.: -He knew the truth as usual. } \\
\text { - She understood his various reasons. }\end{array}$ \\
\hline & $(-E)$ & $\begin{array}{l}\text {-one of the inner world expressing emotion: } \\
\text { 'like, fancy, love, hate, enjoy, relish, marvel, } \\
\text { etc' }\end{array}$ & $\begin{array}{l}\text { e.g.: -He feared his father-in-law } \\
\text { - She understood his various reasons. }\end{array}$ \\
\hline & $\begin{array}{l}(- \\
D)\end{array}$ & $\begin{array}{l}\text {-one of the inner world expressing desideration: } \\
\text { want, plan, decide, resolve, agree, comply, etc }\end{array}$ & $\begin{array}{l}\text { e.g.: - He has planned this for two days } \\
\text { - She resolved to take vengeance. }\end{array}$ \\
\hline \multicolumn{2}{|l|}{$(B P)$} & $\begin{array}{l}\text {-'one that represents the outer manifestation an } \\
\text { inner working/the acting out of a process of } \\
\text { consciousness or a psychological state' }\end{array}$ & $\begin{array}{l}\text { e.g.: -He sighed with relief } \\
\text { - She laughed so loud that her mother } \\
\text { thought her mad. }\end{array}$ \\
\hline$(R P)$ & $(-A)$ & $\begin{array}{l}\text {-one that expresses quality/class-membership: } \\
\text { 'state verb' +adjective/+indefinite noun phrase' }\end{array}$ & $\begin{array}{l}\text { - e.g.: -He was happy. } \\
\text { - He was a happy man. }\end{array}$ \\
\hline
\end{tabular}


Facets of Focalisation and Ideology in the Stream-of Consciousness Mode: A Study of Lawrence Darmani's Grief Child.

\begin{tabular}{|c|c|c|c|}
\hline & $(-I)$ & $\begin{array}{l}\text { 'one that identities: 'state verb'+ definite noun } \\
\text { phrase }\end{array}$ & -e.g.: -Nell was the opposition leader. \\
\hline & $\begin{array}{l}(- \\
C)\end{array}$ & -one that classifies/identifies in a circumstance & -e.g.: -Nell is in a bad mood today. \\
\hline & $(-P)$ & -one that expresses ownership/possession & -e.g.: -Nell owns two big cars. \\
\hline & $(-E)$ & $\begin{array}{l}\text {-one by which an entity is recognized 'to exist': } \\
\text { 'There + 'state verb' + location }\end{array}$ & -e.g.: -There was a man in the garden. \\
\hline$(V P)$ & & $\begin{array}{l}\text { 'one expressing a symbolic relationship } \\
\text { constructed in the consciousness and enacted in } \\
\text { the form of language, like saying and meaning' }\end{array}$ & $\begin{array}{l}\text {-e.g.: -Pascal told me the story of Diana. } \\
\text {-They reported that he had been fired. }\end{array}$ \\
\hline
\end{tabular}

In addition, the sub-identification of $M e P s$ has been inspired by a classification proposed by Matthiessen (1995: 263-70) and rechristened by Halliday and Matthiessen (1999: 137-144; 2004: 208210). However, a few contextual and practical refinements are made. These authors, and myself in earlier studies (Amoussou, 2014; 2017), have kept existential processes separate from other relational processes, while I have kept them together here, for two reasons. First, as can be seen on Table $_{1}$, they have the same nucleus 'verb of state.' Second, the 'there' in existential processes is 'an apparent' subject and thus has no function in Transitivity (Eggins, 2004: 238; Halliday \& Matthiessen, 2004: 257). As a result, the so-called 'there' is a surface manifestation of the extraposition of a circumstance to the end of the clause. The sentence 'An elephant was in the garden' is the deep-structure clause turned into 'There was an elephant in the garden.' The 'existential' clause thus functions on the deep structure as a circumstantial relational one (Eggins, 2004: 238; Halliday \& Matthiessen, 2004: 257).

In addition, though 'meteorological processes' can be construed materially -, e.g.: 'it's raining'; relationally- e.g.: 'it's rainy'; and existentially- e.g.: 'there's rain' (Halliday \& Matthiessen, 2004: 258), they are all taken here as 'MTPs' for the difference in constructions matters little in the context of the present study. Moreover, the difference between 'mental' and 'behavioural' processes is at times hard to grasp. For instance, on one classification table (Halliday \& Matthiessen, 2004: 210) 'to dream' is taken as a cognitive mental process while in another table, the same is classified as 'a behavioural process' (p.251). More than that, most researchers, including myself, would promptly take, for instance, the process 'to sing' as a 'verbal one,' but Halliday and Matthiessen (2004:251) view such verbs describing bodily postures and pastimes as 'to sing, to dance, to lie (down), to sit up, to sit down,...etc' as behavioural processes. Furthermore, some structurally relational processes function to express inner experience (Halliday \& Matthiessen, 2004: 212) and are thus taken as either mental or behavioural processes depending on their contextual semantic import (Amoussou, 2014: 122; 2017: 256). Finally, sentences of interior monologue, in compliance with Fowler's definition (1986: 137), whether direct or indirect, are taken as 'rewriteable mental processes' (MeP-R). The indirect ones are submitted to Barthes' rewrite-test (Barthes, 1975: 262; Genette, 1980:193; RimmonKenan, 1983: 201) to show their interiority (tables 3, 5, 7).

As the five subclasses of mental processes more or less relate to three facets of focalisation (RimmonKenan, 1983:77-82), the latter can be studied through the former. Indeed, while the perceptual facet is encoded in perceptive MePs (Uspensky, 1973: 64; Rimmon-Kenan, 1983: 77), the psychological one involves the mind and emotions and are best expressed through cognitive and emotive ones (RimmonKenan, 1983; Genette, 1980). To the latter, behavioural processes can be added because of the blur between behaviour and cognition (Halliday \& Matthiessen, 2004: 210). As for the ideological facet, it has to do with the standards by which events and characters are presented and evaluated (Uspensky, 1973: 8; Rimmon-Kenan, 1983:81). This facet can thus be decoded through modality and desiderative processes which at times play an evaluative function. In general, these norms are presented through the dominant perspective of the narrator-focaliser and if other ideologies have to emerge in the texts, they tend to become subordinate to that of the dominant focaliser (Uspensky, 1973: 8-9; RimmonKenan, 1983: 81).

\section{ANALYSIS OF THE EXPERIENTIAL FEATURES AND FoCALISATION FACETS In THE TEXTS}

\subsection{Process-Type Identification in the Texts}

For the purpose of the analysis, three extracts, containing 408-432 processes each, are drawn from the novel - Extract 1: [(p.9) "It was midnight......sustaining faith" (p.18)]; Extract 2: [(p.61) "While 
Facets of Focalisation and Ideology in the Stream-of Consciousness Mode: A Study of Lawrence Darmani's Grief Child.

the little village..... on second thought she decided to try" (p.69)] and Extract 3: [(p.121) "That night .....without his permission" (p.129)]. Each text is broken into numbered clauses and the processes in it are identified, labelled and categorized for accurate quantification (tables 2, 4, 6). For space constraints, just about $20 \%$ of each text is displayed in the appendix as a sample for the whole (see Appendix). The next section draws on the experiential data-processing for the analysis of the three texts.

\subsection{Data-Reports and Analyses of Experiential Features in the Texts}

\subsubsection{Data-Report and Analysis of Text1}

The data obtained from the process identification of Text ${ }_{I}$ are reported in the table below to serve as backbone for the analysis.

Table2. Distribution of Process-Types in Text1

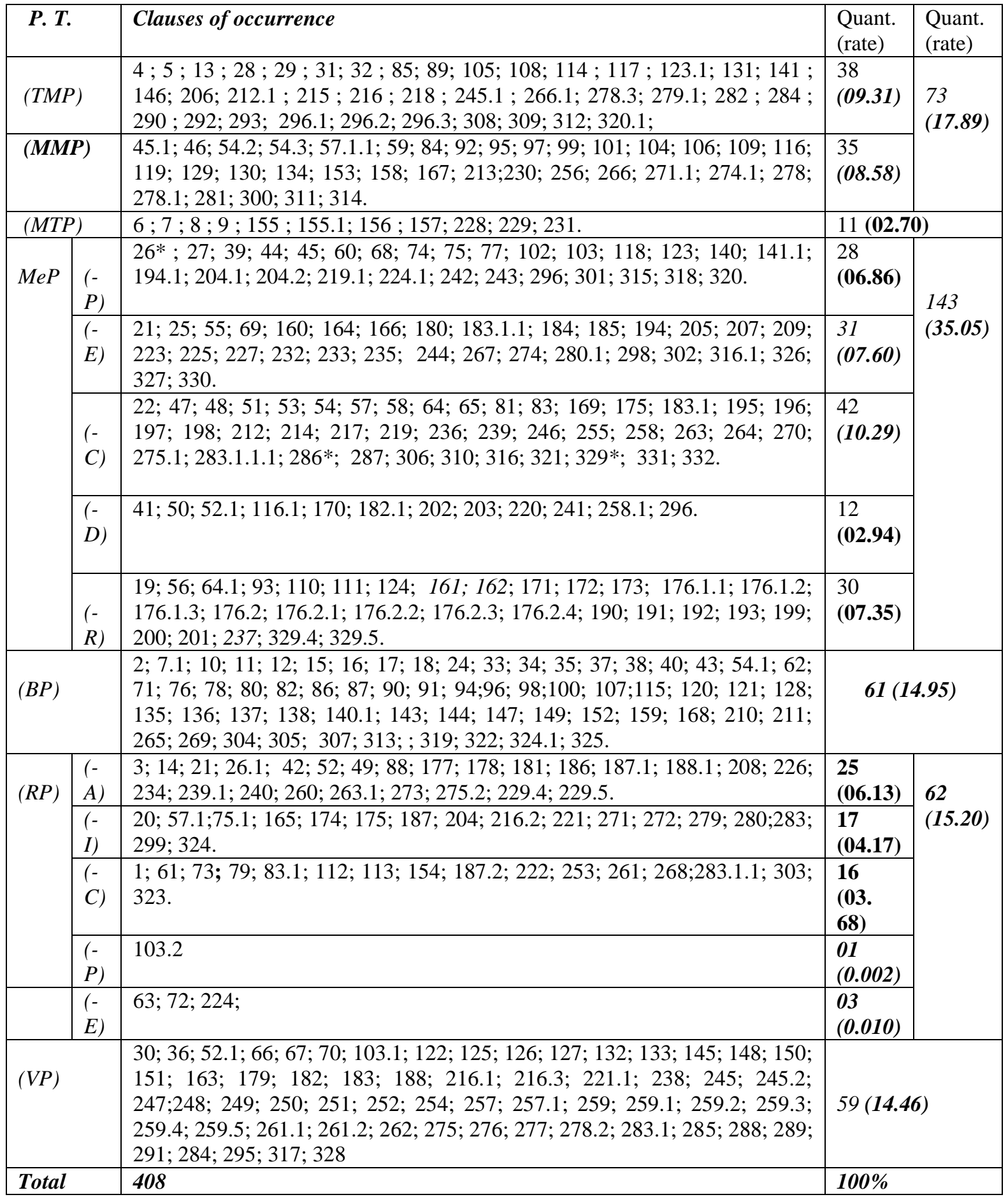


Facets of Focalisation and Ideology in the Stream-of Consciousness Mode: A Study of Lawrence Darmani's Grief Child.

Figures and statistics from this table reveal that four major groups of process significantly occur in this stream of consciousness-dominated extract: TMPs + MMPs $[(09.31 \%)+(08.58)=(\mathbf{1 7 . 8 9 \%})]$; $M e P s+B P s[(35.05 \%)+(14.95 \%)=(\mathbf{5 0 \%})] ; \operatorname{RPs}[(\mathbf{1 5 . 2 0 \%})]$ and VPs $[(\mathbf{1 4 . 4 6 \%})]$, with a sparse occurrence of meteorological processes [MTPs: (02.70\%). In the first group, the comparable rates of $T M P s$ and MMPs mean that the characters in the text are almost equally involved in concrete goaloriented actions as they are in movements from one place to another (Halliday \& Matthiessen, 2004: 180). This group is somehow solaced by the MTPs, which means that characters are subjected to such forces of nature as rains, floods, winds, storms, thunder, lightening, etc. The significant occurrence of VPs means at first sight that the participants are involved in such aspects of speech as saying, telling, narrating, reporting, projecting, etc while the important rate of $R P s$ means that they are involved in such aspects of social relations as revelation of identity, relative definition (Halliday\& Matthiessen, 2004: 214-23)

The overwhelming majority of processes in the second group indicate that characters are primarily involved in such aspects of mental actions as perception, cognition, emotion, desideration and physiological or psychological behaviour. In this group, psychological behaviour and cognition come out more significantly [(14.95\%) \& $(\mathbf{1 0 . 2 9} \%)]$, followed by emotion $[(\mathbf{0 7 . 6 0 \%})]$, direct experience $(07.35 \%)$, perception $(06.86 \%)$, ending with desideration $(02.94 \%)$. The last rate entails that the characters find themselves in situations in which they have little power over their behaviors, perceptions, thoughts and emotions. Maybe, the fact that the text primarily deal with an evil dream, which is beyond the characters' capacity to decide, and their various interpretations, reactions and projections about it, accounts for this distribution of processes in this group.

Indeed, in addition to the dominance of micro-mental and behavioural processes, another distinctive feature of this kind of text seems to be its being built around some salient macro-MePs (Fowler, 1986: 137; Amoussou, 2014: 129; 2017: 255) which govern other process-types. In $\boldsymbol{T}_{\boldsymbol{1}}$, about $\mathbf{0 7}$ macroMePs can be identified to cover substantial text ranges: 'heard' (39): [40-125]; 'didn't like' (170): [171-173]; 'remembered' (176): [176.1-176.2.4]; 'was thinking about' (236): [237-264]; 'took' (270): [271-285]; 'remembered' (286): [286.1- 296.3]; 'thought' (329): [329.1-329.5]. It must be noted that most other process-types (material, meteorological, relational, verbal) are included within these Macro-MePs and BPs. For instances such VPs as ${ }^{0 \mathrm{~s}}$ ' $275 ; 276 ; 277 ; 278.1 ; 283.1 ; 285 ; 288 ; 289$; 291; 294; 295' fall within the cognitive range of the MeP 'took' (270) and/or 'remembered' (286). Likewise the cognitive range of the $M e P$ 'was thinking' (236) includes such VPs as $\mathrm{n}^{0 \mathrm{~s}}$ : 338; 245; $245.2 ; 247 ; 248 ; 249 ; 250 ; 251 ; 252 ; 254 ; 257 ; 257.1 ; 259 ; 259.1 ; 259.2 ; 259.3 ; 259.4 ; 259.5 ; 261.1$; $261.2 ; 262$. The same applies to the other process-types falling within the range either of these macro$M e P s$ or of any aforementioned one.

In addition to the many $M e P s$, this text contains 05 estrangers -'as if' (60); 'sounded like' (68); 'seemed like '(74); 'seemed to' (75), 'as if' (142) - which indicate the subjective interpretation of events by a character-focaliser (Uspensky, 1973: 75; Rimmon-Kenan, 1983: 81; Fowler, 1986: 142; Amoussou, 2016: 245, 256; 2017: 255; 262). Another feature is certainly the occurrence of strings of internal monologue and soliloquy, whether direct or narrated: (19); (56); (64.1); (93); (110); (111); (124); (161); (162); (171); (172); (173); (190); (191); (192); (193); (199); (200); (201); (237). The rewrite-test (Barthes, 1975: 262) is applied to some of the narrated monologue strings to show the difference in their surface structure and deep structure configurations. Table 5 shows their narratorial surface structure versions (a) and rewritten or deep structure ones (b):

Table3. Application of the rewrite-test to a few MeP-Rs from text 1

\begin{tabular}{|l|l|l|}
\hline \multicolumn{1}{|c|}{$\boldsymbol{n}^{\mathbf{0}}$} & Narratorial versions & Rewritten versions \\
\hline$(64.1)$ & $(\boldsymbol{a})$ 'How did he come to be here?'] & (b) 'How do I come to be here?'] \\
\hline$(110-11)$ & $\begin{array}{l}\text { ['Did he not love plants, the trees and the } \\
\text { birds?']['Why had they now deserted him?' }\end{array}$ & $\begin{array}{l}\text { (b) ['Do I not love plants, the trees and the } \\
\text { birds?'] ['Why have they now deserted me?' }\end{array}$ \\
\hline $\begin{array}{l}\text { (161-62) } \\
\begin{array}{l}\text { was ['One moment everything and everybody } \\
\text { by his family...] }\end{array}\end{array}$ & $\begin{array}{l}\text { (b) ['One moment everything and everybody } \\
\text { is against me] [Now I am surrounded by my } \\
\text { family...]. }\end{array}$ \\
\hline$(173)$ & $\begin{array}{l}\text { (a) [Why would a member of his own family } \\
\text { be seeking to destroy his son?] }\end{array}$ & $\begin{array}{l}\text { (b) [Why will a member of my own family be } \\
\text { seeking to destroy my son?] }\end{array}$ \\
\hline$(190-91))$ & $\begin{array}{l}\text { (a) [Why did he remember all this?] [Why } \\
\text { (b) [Why do I remember all this?] [Why does }\end{array}$ \\
\hline
\end{tabular}


Facets of Focalisation and Ideology in the Stream-of Consciousness Mode: A Study of Lawrence Darmani's Grief Child.

\begin{tabular}{|l|l|l|}
\hline & $\begin{array}{l}\text { did his son's dream awaken all these } \\
\text { memories?] }\end{array}$ & my son's dream awaken all these memories?] \\
\hline (237) & (a) [This Nimo surprised him!] & (b) [This Nimo surprises me!] \\
\hline
\end{tabular}

From this first analysis, it can strongly be posited that the stream-of-consciousness-mode or 'internally-focalized discourse' (Rimmon-Kenan, 1983; Uspensky, 1973; Amoussou, 2014; 2017) is likely to be dominated by MePs-BPs, to contain macro-MePs, strings of direct or rewritable monologue and words of estrangements. These features entail that this discourse mode foregrounds various aspects of mentality and behaviour while aspects of materiality, relationality and verbality are phagocytised by the former. The next section analyses the second extract to see whether or not it has the same features as the first one.

\subsubsection{Data-Report and Analysis of Text2}

The table below sums up the data obtained from the process-type identification of Text2.

Table4. Distribution of Process-Types in Text2

\begin{tabular}{|c|c|c|c|c|}
\hline \multicolumn{2}{|l|}{$P . T$. } & Clauses of occurrence & $\begin{array}{l}\text { Quant. } \\
\text { (rate) }\end{array}$ & $\begin{array}{l}\text { Quant. } \\
\text { (rate) }\end{array}$ \\
\hline \multicolumn{2}{|c|}{$(\mathrm{TMP})$} & $\begin{array}{l}6.1 ; 12 ; 16 ; 17 ; 24 ; 39.2 .1 ; 40 ; 44.3 .3 ; 43.3 .4 ; 57 ; 63.2 ; 63.3 ; \\
64.1 ; 78 ; 84 ; 86 ; 87 ; 88 ; 89 ; 91 ; 100 ; 101 ; 118.1 .2 ; 144 ; 168 ; 181 ; \\
189 ; 190 ; 192 ; 194 ; 196 ; 197.1 ; 199 ; 205.1 ; 206 ; 210.2 ; 222 ; 227 \text {, } \\
242 ; 243 ; 244 ; 249 ; 250 ; 260 ; 299 ; 315 .\end{array}$ & 46 & \multirow[t]{2}{*}{$\begin{array}{l}71 \\
(17.11 \%)\end{array}$} \\
\hline \multicolumn{2}{|c|}{$(\boldsymbol{M M P})$} & $\begin{array}{l}18 ; 25 ; 39.1 .10 ; 42.2 ; 43.3 .2 .1 ; 56 ; 83 ; 145 ; 146 ; 151 ; 157 ; 185 ; 186 ; \\
201 ; 203 ; 216 ; 221 ; 247 ; 254 ; 259.1 ; 263 ; 278 ; 297 ; 306 ; 311 . .\end{array}$ & $\begin{array}{l}25 \\
(06.02 \%)\end{array}$ & \\
\hline \multicolumn{2}{|c|}{$(M T P)$} & $\begin{array}{l}2 ; 3 ; 4 ; 5.1 ; 5.2 ; 5.3 ; 13 ; 15 ; 19 ; 21.1 ; 22 ; 26 ; 27 ; 28 ; 30 ; 31 ; \\
31.1 ; 32.1 ; 33 ; 34 ; 35 ; 39.1 .7 ; 39.1 .8 ; 39.1 .11 ; 44.1 ; 44.3 .1 ; \\
44.3 .2 ; 69 ; 72 ; 126.1 ; 138.1 ; 139 ; 140 ; 141.2 ; 142 ; 143 ; 184 ; 202 \\
309 ; 310 . .\end{array}$ & $\begin{array}{l}40 \\
(09.64 \%)\end{array}$ & \\
\hline \multirow[t]{5}{*}{$\mathrm{MeP}$} & $(-P)$ & $\begin{array}{l}5 ; 21 ; 32 ; 52 ; 67 ; 71 ; 74 ; 118 * ; 124 ; 178 ; 187.1 ; 197 ; 204 ; 224 ; 230 ; \\
259 ; 254 ; 269 ; 271 ; 272 .\end{array}$ & $\begin{array}{l}20 \\
(04.49 \%)\end{array}$ & \multirow{5}{*}{$\begin{array}{l}132 \\
(31.81 \%)\end{array}$} \\
\hline & $(-E)$ & $\begin{array}{l}43 ; 44.3 * ; 53 ; 68 ; 121 ; 144.1 ; 149.2 ; 158 ; 165 ; 170 ; 174 ; 177 ; 198 ; \\
231 ; 281 ; 283 .\end{array}$ & 16 & \\
\hline & $(-C)$ & $\begin{array}{l}6 ; 38 ; 39 * ; 41 ; 42 * ; 44 * ; 45 ; 63 * ; 81 ; 103 ; 126 * ; 134 ; 141 ; 148 * ; \\
149^{*} ; 153 * ; 155 ; 162 ; 169.1 ; 172 ; 175 ; 210 ; 211 ; 212 ; 213 ; 214 ; 215 ; \\
218 ; 219 ; 233 ; 234 ; 235 ; 236 ; 237 ; 239 ; 240 ; 241.1 ; 246.1 ; 252 ; 253 \\
256 ; 282 ; 285 ; 286 ; 294 ; 295 ; 286 ; 308 ; 317 ; 325 ; 327 ; 328 ; 332 \\
332.2 .\end{array}$ & $\begin{array}{l}54 \\
(13.01 \%)\end{array}$ & \\
\hline & $(-D)$ & $1 ; 39.1 .3 .1 ; 135 ; 156^{*} ; 167 ; 173 ; 200 ; 207 ; 288 ; 292 ; 316 ; 334$. & $\begin{array}{l}12 \\
(\mathbf{0 2 . 8 9})\end{array}$ & \\
\hline & $(-R)$ & $\begin{array}{l}11 ; 20 ; 42.1 ; 42.2 ; 42.3 ; 42.4 ; 42.5 ; 42.6 ; 42.7 ; 55 ; 105 ; 160 ; 232 ; \\
235.1 ; 235.2 ; 235.3 ; 235.3 .1 ; 307 ; 307.1 ; 307.2 ; 318 ; 319 ; 320 ; 321 ; \\
322 ; 323 ; 324 ; 329 ; 330 ; 333 . .\end{array}$ & $\begin{array}{l}30 \\
(07.23 \%)\end{array}$ & \\
\hline \multicolumn{2}{|l|}{$(\boldsymbol{B P})$} & $\begin{array}{l}8 ; 29 ; 37 ; 39.1 .6 ; 39.1 .9 ; 44.5 ; 46 ; 47 ; 48 ; 49 ; 50 ; 51 ; 52.1 ; 54 ; 59 ; \\
60 ; 65 ; 66 ; 70 ; 75 ; 76 ; 77 ; 82 ; 90 ; 92 ; 98 ; 99 ; 104 ; 106 ; 108 * ; 111.1 ; \\
113 ; 114 ; 115 ; 123 ; 124.1 ; 125 ; 132 ; 148.1 ; 159 ; 205 ; 208 ; 209 ; 217 \text {; } \\
220 ; 228 ; 229 ; 238 ; 248 ; 251 ; 257 ; 258 ; 265 ; 266 ; 267 ; 268 ; 270 ; \\
271 ; 273 ; 275 ; 276 ; 277 ; 280 ; 284 ; 298 ; 300 ; 302 .\end{array}$ & \multicolumn{2}{|l|}{$\begin{array}{c}67 \\
(\mathbf{1 6 . 1 4 \%})\end{array}$} \\
\hline \multirow[t]{5}{*}{$(R P)$} & $(-A)$ & $44.3 .5 ; 73 ; 80 ; 83.1 ; 137 ; 180 ; 193 ; 210.1 ; 246 ; 255 ; 293 ; 331$. & $\begin{array}{l}12 \\
(2.89)\end{array}$ & \multirow[t]{5}{*}{$\begin{array}{l}54 \\
(13.01 \%)\end{array}$} \\
\hline & $(-I)$ & $36 ; 38.1 ; 39.1 .3 ; 39.1 .4 ; 55 ; 64 ; 138 ; 141.1 ; 182 ; 191 ; 241 ; 298.1$. & $\begin{array}{l}12 \\
(2.89)\end{array}$ & \\
\hline & $(-C)$ & $\begin{array}{l}5.4 ; 9 ; 10 ; 23 ; 39.1 .1 ; 39.1 .5,85 ; 97 ; 102 ; 105 ; 107 ; 109 ; 110 ; 116 ; \\
120 ; 149.1 ; 154 ; 163 ; 171 ; 176 ; 179 ; 182.1 ; 187 ; 188 ; 195 ; \\
245 ; 274 ; 326 .\end{array}$ & $28(6.51)$ & \\
\hline & $(-P)$ & 00 & 00 & \\
\hline & $(-E)$ & $183 ; 332.1$ & $02(0.07)$ & \\
\hline
\end{tabular}


Facets of Focalisation and Ideology in the Stream-of Consciousness Mode: A Study of Lawrence Darmani's Grief Child.

\begin{tabular}{|l|l|l|}
\hline$(\boldsymbol{V P})$ & $7 ; 39.1 * ; 58 ; 61 ; 62 ; 63.1 ; 77.1 ; 79 ; 93 ; 94 ; 95 ; 96 ; 103.1 ; 111 ; 112 ;$ & \\
& $117 ; 118.1 ; 118.1 .1 ; 118.1 .3 ; 119 ; 122 ; 127 ; 128 ; 129 ; 130 ; 131 ; 133 ;$ & \\
& $136 ; 147 ; 150 ; 152 ; 153.1 ; 161 ; 166 ; 169^{*} ; 199.1 ; 223 ; 225 ; 226 ; 279 ;$ & $\mathbf{5 2}(\mathbf{1 2 . 5 3})$ \\
& $287 ; 289 ; 290 ; 291 ; 301 ; 303 ; 304 ; 305 ; 308.1 ; 312 ; 313 ; 314 .$. & \\
\hline Total & $\mathbf{4 1 5}$ & $\mathbf{1 0 0 \%}$ \\
\hline
\end{tabular}

From the table, it can once again be read that four major groups of process emerge: TMPs $+M M P s$ $[(11.08 \%)+(06.02 \%)=(\mathbf{1 7 . 1 1 \%})] ; \mathrm{MePs}+\mathrm{BPs}[(31.81 \%)+(16.14 \%)=(\mathbf{4 7 . 9 6 \%})] ; R P s$ [(13.01\%)], and VPs [(12.53\%)], with a more significant proportion of MTPs [(09.64\%)]. While the significant occurrence of TMPs and MMPs means that the participants are involved in plot-significant actions, be they in terms of goal-impacting processes or movement-involving ones. This reflects the field of discourse: the text depicts dream attacks in which a faceless woman attacks twice and overpowers Birago, the focal character in the text, and her daughter Yaa ([45-103] \& [233-263]). The more significant occurrence of meteorological processes means that natural forces are at play with those of darkness in afflicting the characters. Indeed, though the two female characters are overpowered in their dreams by the faceless woman, they are crushed by a falling tree branch during a rainstorm (p.73). While the important rate of RPs means that characters are involved in such aspects of social relations as identity statements, relative definitions, quality attributions, circumstance statements, the relative occurrence of VPs means at first sight that the participants are involved in such aspects of speech as saying, telling, narrating, reporting, projecting. A major distinctive feature of this text is the dominance of $M e P s+B P s$. In this group, BPs still come top (16.14\%), followed by cognitive $\mathrm{MePs}$ (13.01\%), rewritable ones $(\mathbf{0 7 . 2 3 \%})$, perceptive ones $(\mathbf{0 4 . 4 9 \% )}$, with emotive and desiderative ones occurring almost sparingly: (03.86\%) and (02.89\%), respectively.

Just like $\boldsymbol{T}_{\boldsymbol{1}}$, this text $\left(\boldsymbol{T}_{2}\right)$ also contains a few macro-mental processes: 'heard' (5): [5.1-5.4]; 'wondered' (6): [6.1-10]; 'lay listening'(29): [30-38.1]; 'remembered': [39.1-39.1.11]; 'thought about' (42): [42.1-42.7]; 'didn't like' (44.3): [44.3.1- 44.5]; 'heard' (52): [52.1-60]; 'remembered' (63): [63.1-63.3]; 'could hear' (118): [118.1-121]; 'was forced to think about' (162): [163-178]; 'understood' (153): [153.1-160]; 'thought' (235): [235.1-235.3.1]; 'began to unravel' (240): [241263]. A few estrangers can also be found in this text: 'surely' (55); 'as if' (121); 'it seemed that' (138); 'seemed to' (169); 'seemed like' (245).

The table below applies the rewrite test (Barthes, 1975: 262) to 5 strings of this extract to show the difference between their surface/narrated versions and their deep/direct ones:

Table5. Application of the rewrite-test to a few MeP-Rs from text2

\begin{tabular}{|c|c|c|}
\hline$n^{0 s}$ & Narratorial versions & Rewritten versions \\
\hline$(42.3)$ & $\begin{array}{l}\text { (a) [To make matters worse, her husband often } \\
\text { tried to hide the problem from her]. }\end{array}$ & $\begin{array}{l}\text { (b) [To make matters worse, my husband often } \\
\text { tries to hide the problem from me]. }\end{array}$ \\
\hline $\begin{array}{l}\text { (235.2- } \\
235.3) \\
\end{array}$ & $\begin{array}{l}\text { (a) [Even if she were to ask her about it] [she } \\
\text { knew instinctively] that Yaa would not remember } \\
\text { a thing]. }\end{array}$ & $\begin{array}{l}\text { (b) [Even if I were to ask her about it] }[\mathbf{I} \text { know } \\
\text { instinctively] that Yaa would not remember a } \\
\text { thing]. }\end{array}$ \\
\hline$(307)$ & $\begin{array}{l}\text { (a) [She was sure][that her mother yelled in } \\
\text { fright] }\end{array}$ & $\begin{array}{l}\text { (b) [ I am sure][that my mother yelled in } \\
\text { fright] }\end{array}$ \\
\hline (318) & $\begin{array}{l}\text { (a) [Why had her mother screamed the way she } \\
\text { did?] }\end{array}$ & $\begin{array}{l}\text { (b) [Why has my mother screamed the way she } \\
\text { did?] }\end{array}$ \\
\hline (320) & $\begin{array}{l}\text { (a) [Yet she had never seen or heard her mother } \\
\text { show fear]. }\end{array}$ & $\begin{array}{l}\text { (b) [Yet I have never seen or heard my mother } \\
\text { show fear]. }\end{array}$ \\
\hline
\end{tabular}

\subsubsection{Data-Report and Analysis of Text 3}

Like Tables 2 and 5, this one recaps the data used for the analysis of Extract 3.

Table6. Distribution of Process-Types in Text 3

\begin{tabular}{|l|c|l|l|}
\hline P.T. & Clauses of occurrence & Quant. (rate) & Quant. (rate) \\
\hline & $7 ; 21.1 ; 26 ; 30 ; 31 ; 32 ; 36.1 ; 42.1 ; 45 ; 59 ; 60 ; 69 ; 72 ; 74 ;$ & $\mathbf{3 4}$ & \\
$(\boldsymbol{T M P})$ & $91.2 ; 96.1 ; 96.3 ; 128 ; 129 ; 141 ; 155 ; 192 ; 234 ; 240 ; 281.1 ;$ & $(\mathbf{0 7 . 8 7 \% )}$ & $\mathbf{8 4}$ \\
\hline
\end{tabular}


Facets of Focalisation and Ideology in the Stream-of Consciousness Mode: A Study of Lawrence Darmani's Grief Child.

\begin{tabular}{|c|c|c|c|c|}
\hline & $309 ; 321 ; 328 ; 332 ; 335.1 ; 342 ; 343 ; 344 ; 354$. & & \multirow[t]{2}{*}{$(19.44)$} \\
\hline$(M M)$ & & $\begin{array}{l}17 ; 18 ; 20 ; 21 ; 22 ; 27 ; 29 ; 34 ; 35 ; 43 ; 44 ; 63 ; 67 ; 68 ; 73 ; 75 ; 92 ; \\
96.2 ; 139 ; 151 ; 152 ; 176 ; 177 ; 178 ; 180 ; 181.1 ; 187 ; 188 ; 191 ; \\
204 ; 220 ; 229 ; 267 ; 273 ; 276 ; 277 ; 278 ; 281.1 ; 307.1 ; 307.2 ; \\
310 ; 320 ; 322 ; 355 ; 356 ; 358 ; 359 ; 361 ; 362.1 ; 374 .\end{array}$ & $\begin{array}{l}50 \\
(11.16 \%)\end{array}$ & \\
\hline \multicolumn{2}{|c|}{$($ MTP $)$} & $161 ; 165 ; 296 ; 297 ; 298$ & \multicolumn{2}{|l|}{$05(01.16 \%)$} \\
\hline \multirow[t]{5}{*}{$\mathrm{MeP}$} & $\begin{array}{l}(- \\
P)\end{array}$ & $\begin{array}{l}3 ; 9 ; 20.1 ; 23 ; 36 ; 38 ; 46 ; 53 ; 70 ; 106 ; 113 ; 115 ; 116 ; 123 ; 133 ; \\
140 ; 142 ; 154 ; 163.1 ; 164 ; 166 ; 198.1 ; 206 ; 208 ; 218 ; 221 ; 228 \\
253 ; 268 ; 270 ; 286 ; 302.1 ; 307 ; 308 ; 315 ; 325 ; 357 ; 376 .\end{array}$ & $\begin{array}{l}38 \\
(08.80 \%)\end{array}$ & \multirow{5}{*}{$\begin{array}{l}197 \\
(45.6 \%)\end{array}$} \\
\hline & $\begin{array}{l}(- \\
E)\end{array}$ & $\begin{array}{l}15 ; 16 ; 16.2 ; 54 ; 61 ; 86 ; 91.1 ; 102 ; 105 ; 111 ; 111.1 ; 117 ; 120 ; \\
124 ; 125 ; 130 ; 167 ; 171 ; 171.1 ; 174 ; 197 ; 198.2 ; 210 ; 239 ; \\
239.1 ; 241 ; 301 ; 337 ; 339 ; 340 .\end{array}$ & $\begin{array}{l}30 \\
(06.94 \%)\end{array}$ & \\
\hline & (- & $\begin{array}{l}10 ; 10.1 ; 42 ; 93 ; 98 ; 109 ; 110 ; 112 ; 118 ; 118.1 ; 147 ; 148 ; 163 ; \\
172 ; 179 ; 181 ; 188.1 ; 196 ; 198 ; 201 ; 202 ; 205 ; 205.1 ; 207 ; 213 ; \\
223 ; 224 ; 227.1 ; 232 ; 251 ; 252 ; 265 ; 269 ; 269.1 ; 281 ; 288 ; 290 ; \\
319 ; 336 ; 342.1 ; 350 ; 366 .\end{array}$ & $\begin{array}{l}42 \\
(09.72 \%)\end{array}$ & \\
\hline & $\begin{array}{l}(- \\
D)\end{array}$ & $\begin{array}{l}2 ; 5 ; 6 ; 58 ; 84 ; 89 ; 101 ; 108 ; 131 ; 143 ; 144 ; 156 ; 160 ; 175 ; 200 ; \\
209.1 ; 210.1 ; 214 ; 227 ; 234 ; 270.1 ; 272 ; 274 ; 290.1 ; 291 ; .292 ; \\
293 ; 318 .\end{array}$ & $\begin{array}{l}28 \\
(06.48 \%)\end{array}$ & \\
\hline & $\begin{array}{l}(- \\
R)\end{array}$ & $\begin{array}{l}55 ; 107 ; 115.1 ; 115.2 ; 115.3 ; 115.4 ; 119 ; 132 ; 137 ; 138 ; 145 ; \\
149 ; 150 ; 150.1 ; 168 ; 169 ; 170 ; 173 ; 183 ; 185 ; 186 ; 189 ; 201.1 ; \\
203 ; 211 ; 212 ; 232.3 ; 232.4 ; 242 ; 243 ; 244 ; 245 ; 246 ; 247 ; 248 ; \\
249 ; 257 ; 258 ; 259 ; 260.1 ; 266 ; 294 ; 303 ; 313 ; 317 ; 352 ; 360 ; \\
363 ; 364 ; 365 ; 367 ; 368 ; 369 ; 370 ; 371 ; 372 ; 373 ; 377 ; 378 ;\end{array}$ & $\begin{array}{l}59 \\
(13.66 \%)\end{array}$ & \\
\hline \multicolumn{2}{|l|}{$(\boldsymbol{B P})$} & $\begin{array}{l}1 ; 4 ; 5.2 ; 9.1 ; 11 ; 16.1 ; 19 ; 24 ; 25 ; 33 ; 37 ; 39 ; 40 ; 41 ; 46.1 ; 47 ; \\
48 ; 52 ; 53.1 ; 53.2 ; 56 ; 57 ; 62 ; 64 ; 65 ; 71 ; 94 ; 97 ; 99 ; 100 ; 103 ; \\
114 ; 121 ; 122 ; 127 ; 134 ; 135 ; 136 ; 146 ; 157 ; 193 ; 194 ; 199 ; \\
230 ; 233 ; 238 ; 255 ; 279 ; 280 ; 283 ; 284 ; 285 ; 286.1 ; 287 ; 299 ; \\
300 ; 302 ; 304 ; 305 ; 306 ; 316 ; 323 ; 324 ; 326 ; 329 ; 338 ; 362 ; \\
375 .\end{array}$ & \multicolumn{2}{|c|}{$68(15.74 \%)$} \\
\hline \multirow{5}{*}{$(R P)$} & $\begin{array}{l}(- \\
A)\end{array}$ & $\begin{array}{l}8 ; 13 ; 49 ; 51 ; 83 ; 162 ; 176.1 ; 182 ; 188.2 ; 195 ; 222 ; 226.3 ; \\
256.1 ; 271,273.1 ; 282 ; 295 ; 334 .\end{array}$ & $18(04.17 \%)$ & \multirow{5}{*}{$46(10.65 \%)$} \\
\hline & $\begin{array}{l}(- \\
I)\end{array}$ & $14 ; 184 ; 254 ; 336.1 ; 351$. & $05(01.16 \%)$ & \\
\hline & (- & $\begin{array}{l}28 ; 50 ; 66 ; 126 ; 152.1 ; 153 ; 158 ; 159 ; 172.1 ; 190 ; 216 ; 217 ; \\
219 ; 226 ; 226.2 ; 236 ; 256 ; 261 ; 275,333 .\end{array}$ & $\begin{array}{l}20 \\
(05 \%)\end{array}$ & \\
\hline & $\begin{array}{l}(- \\
P)\end{array}$ & 289 & $01(0.02 \%)$ & \\
\hline & $\begin{array}{c}(- \\
E)\end{array}$ & $209 ; 314$. & $02(0.05 \%)$ & \\
\hline \multicolumn{2}{|c|}{$(V P)$} & $\begin{array}{l}5.1 ; 76 ; 77 ; 78 ; 79 ; 80 ; 81 ; 82 ; 85 ; 87 ; 88 ; 90 ; 225 ; 226.1 ; \\
228.1 ; 231 ; 232.1 ; 235 ; 250 ; 254.1 ; 261.1 ; 262 ; 263 ; 264 ; \\
311 ; 312 ; 327 ; 330 ; 331 ; 335 ; 341 ; 345 ; 346 ; 347 ; 348 ; 349 \\
353 .\end{array}$ & \multicolumn{2}{|l|}{$37(10.65 \%)$} \\
\hline \multicolumn{2}{|l|}{ Total } & 432 & \multicolumn{2}{|l|}{$100 \%$} \\
\hline
\end{tabular}

Data from this table lead to similar deductions as those from tables 4 and 6 . Here the combination 'MePs $+\operatorname{BPs}^{\prime}[(45.6 \%)+(15.74 \%)=(61.34 \%)]$ ranks even higher, with BPs still on the lead,

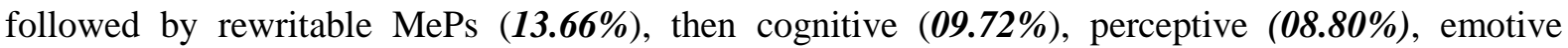

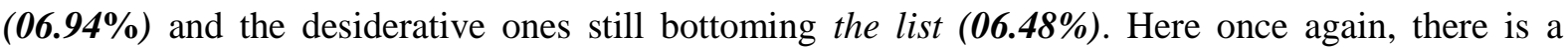
number of macro-MePs: 'had a nightmare' (1): [2-64]; 'thought' (112): [113-119]; 'ignored' (131): [132-150.1]; 'feared' (210): [210.1 -232.4]; 'burned' (241): [242 -266]; 'knew' (269): [269.1 -272]; 'doubted' (290): [290.1 -295]; 'saw' (307): [308-378]; 'heard' (308): [309-378]. As the bracketed text-range after each macro-MeP indicates, these macros encompass most of the other process-types. For instance, all the VPs in section [309-378] fall within the perceptual range of the macro-MeP 'heard' (308) just as all the MPs and RPs within [308-378] are included within that of ' $s a w$ ' (307). 
Facets of Focalisation and Ideology in the Stream-of Consciousness Mode: A Study of Lawrence Darmani's Grief Child.

Indeed, whatever the focal character sees others do and hears them say falls within his perceptual range as indicated by the mental process.

In addition to the numerous $M e P s$, there are 07 estrangers - 'as if' (7); 'was about to' (10.1); 'seemed to' $(45,158,162)$; 'perhaps' (150); 'did...seem to' (313) - which indicate the subjective interpretation of events by the character-focaliser (Uspensky, 1973: 75; Rimmon-Kenan, 1983: 81; Fowler, 1986: 142; Amoussou, 2016: 245, 256; 2017: 255; 262)

The table below shows the narratorial versions $(\boldsymbol{a})$ and rewritten ones $(\boldsymbol{b})$ of a few rewriteable sentences in T3:

Table7. application of the rewrite-test to a few MeP-Rs from text3

\begin{tabular}{|c|c|c|}
\hline $\mathrm{n}^{0 \mathrm{~s}}$ & Narratorial versions & \begin{tabular}{|l|} 
Rewritten versions \\
\end{tabular} \\
\hline (55) & (a) "Was that his aunt?" & (b) "Is this my aunt?" \\
\hline $\begin{array}{l}(115.1)- \\
(115.2)\end{array}$ & $\begin{array}{l}\text { (a) [Wasn't this his father at peace?] } \\
\text { (a) [Did his mother know any suffering now?] }\end{array}$ & $\begin{array}{l}\text { (b) [Isn't this my father at peace?] } \\
\text { [Does my mother know any suffering now?] }\end{array}$ \\
\hline $\begin{array}{l}(211)- \\
(212)\end{array}$ & $\begin{array}{l}\text { (a) [No, he wouldn't recall him]; [that person } \\
\text { would spoil his plans]. }\end{array}$ & $\begin{array}{l}\text { (b) [No, I won't recall him]; [this person } \\
\text { will spoil my plans]. }\end{array}$ \\
\hline $\begin{array}{l}(244)- \\
247\end{array}$ & $\begin{array}{l}\text { (a) [His father was dead] [His mother was dead] } \\
\text { [He had no relative who cared for him] [Wasn't } \\
\text { his life finished?] }\end{array}$ & $\begin{array}{l}\text { (a) [My father is dead] [My mother was } \\
\text { dead] [I have no relative who cares for me } \\
\text { [Isn't my life finished?] }\end{array}$ \\
\hline$(313)$ & $\begin{array}{l}\text { (a) [Why did Adu seem to recognize the second } \\
\text { voice?] }\end{array}$ & $\begin{array}{l}\text { (b) (a) [Why do I seem to recognize the } \\
\text { second voice?] }\end{array}$ \\
\hline (352) & $\begin{array}{l}\text { (a) [But how could the man he knew be party to a } \\
\text { deed like that?] }\end{array}$ & $\begin{array}{l}\text { (b) [But how can the man I know be party to } \\
\text { a deed like this?] }\end{array}$ \\
\hline
\end{tabular}

4. ReCAPitulation, Discussion AND Interpretation: Focalization FaCETS AND IDEOLOGY

The major findings from the analyses of the three texts are summed up in the table below

Table8. Process-type Distribution in the three Texts, inspired from Tables 2, 4 \& 6

\begin{tabular}{|c|c|c|c|c|c|c|c|c|}
\hline \multicolumn{2}{|c|}{ Process Types } & Text $_{1}$ & Text $_{2}$ & Text $_{3}$ & \multicolumn{2}{|c|}{ overall quantities } & \multicolumn{2}{|c|}{ Overall rates } \\
\hline \multirow[t]{2}{*}{$M P$} & $T M P$ & 38 & 46 & 34 & 118 & \multirow[t]{2}{*}{228} & $09.40 \%$ & \multirow[b]{2}{*}{$18.17 \%$} \\
\hline & $M M P$ & 35 & 25 & 50 & 110 & & $08.76 \%$ & \\
\hline \multicolumn{2}{|l|}{$M T P$} & 11 & 40 & 05 & \multicolumn{2}{|l|}{56} & \multicolumn{2}{|c|}{$04.46 \%$} \\
\hline \multirow{5}{*}{$M e P$} & $(-P)$ & 28 & 20 & 38 & 86 & \multirow{5}{*}{472} & $06.85 \%$ & \multirow{5}{*}{$37.61 \%$} \\
\hline & $(-E)$ & 31 & 16 & 30 & 77 & & $06.14 \%$ & \\
\hline & $(-C)$ & 42 & 54 & 42 & 138 & & $11 \%$ & \\
\hline & $(-D)$ & 12 & 12 & 28 & 52 & & $04.14 \%$ & \\
\hline & $(-R)$ & 30 & 30 & 59 & 119 & & $09.48 \%$ & \\
\hline \multicolumn{2}{|l|}{$B P$} & 61 & 67 & 68 & \multicolumn{2}{|l|}{196} & \multicolumn{2}{|c|}{$15.62 \%$} \\
\hline \multirow{5}{*}{$R P$} & $(-A)$ & 25 & 12 & 18 & 55 & \multirow{5}{*}{184} & $04.38 \%$ & \multirow{5}{*}{$14.66 \%$} \\
\hline & $(-I)$ & 17 & 12 & 05 & 34 & & $02.71 \%$ & \\
\hline & $(-C)$ & 15 & 27 & 42 & 84 & & $06.69 \%$ & \\
\hline & $(-P)$ & 01 & 00 & 01 & 02 & & $00.16 \%$ & \\
\hline & $(-E)$ & 04 & 03 & 02 & 09 & & $00.72 \%$ & \\
\hline \multicolumn{2}{|l|}{$V P$} & 59 & 52 & 37 & \multicolumn{2}{|l|}{148} & \multicolumn{2}{|c|}{$11.79 \%$} \\
\hline \multicolumn{2}{|c|}{ Sum Total } & 408 & 415 & 432 & \multicolumn{2}{|c|}{1255} & \multicolumn{2}{|l|}{$100 \%$} \\
\hline
\end{tabular}

These figures help to confirm the trend set by the findings from $\boldsymbol{T} \mathbf{1}$ and validated by those of $\boldsymbol{T} \mathbf{2}$ and T3. As it unfolds, the ' $M e P s+B P s$ ' class ranks highest in all, 53.23\%, followed by 'TMPs + MMPs' (18.17\%), RPs (14.66\%), VPs (11.79\%) and ending with MTPs (04.46\%).

The overwhelming majority of processes in the first group over others helps not only to shatter the claim that material processes always dominate in a transitivity analysis (Amoussou, 2014: 121) but also to confirm that the writer's approach to character revelation (external or internal approach) is the basic rationale behind the distribution of process-types and that the modes of narration and focalisation must be taken into account for the application of SFL-theories to fiction (Amoussou, 2014: 132; 2017: 263). 
In the dominant class, processes of behaviour, cognition, and direct experience rank higher in that order in all the three extracts. 'If by two or three witnesses, truth can be established' (Deuteronomy 17: 6; 19: 15; Matthew 18: 16; John 8: 17; 2 Corinthians 13:1), the sharing of similar features by the three texts can help to postulate and validate a theory that in a stream-of-consciousness mode mental and behavioural processes tend to be foregrounded while material, relational and verbal ones tend to be suspended or backgrounded. This foregrounding is backed up by the occurrence of macro-MePs and $B P S$ in all the extracts to contain, introduce, report and project other processes.

From the distribution of processes in the ' $M e P s+B P s$ ' class, the facets of focalization is deduced. The psychological facet, with a combination of its cognitive component and its emotive one (RimmonKenan, 1983: 79-81; Amoussou, 2017: 128-29) accounts for 26.62\%, as it must take into account the rates of ' $\mathrm{MeP}-\mathrm{C}$ ' $(\mathbf{1 1 \%})$, ' $\mathrm{MeP}-\mathrm{E}^{\prime}$ ' $(\mathbf{0 6 . 1 4 \% )}$ and ' $M e P-R$ ' $(\mathbf{0 9 . 4 8 \% )}$. As for the perceptual facet, it represents $\mathbf{2 2 . 4 7 \%}$ as it is encoded through the perceptive $M e P s(\mathbf{0 6 . 8 5 \%})$, to which behavioural processes (15.62\%) must be added (Halliday \& Matthiessen, 2004:171; 251). As concerns the ideological facet, it is expressed mainly through desideration $(\mathbf{0 4 . 1 4 \%})$ and modality. Indeed, though the four main sub-classes of mental processes can function to express such aspects of metaphorical modality as 'evidentiality' (perceptive), 'epistemic modality' (cognitive), 'deontic modality' (desiderative) and 'evaluative modality' (emotive) (Halliday \& Matthiessen, 1999: 137- 44; 2004: 208), the 17 estrangers contribute to modalisation in helping not only to subjectivise perceptions and observations but also to mark their speculative nature.

Indeed, the significant proportions of cognitive, behavioural, perceptive and emotive processes adequately reflect the characters' involvement in, and reactions to, strange dreams and apparitions, as is solaced by the significant occurrence of the circumstantial 'there'. Indeed, the dichotomy between the existential 'there' and the circumstantial one (Eggins, 2004: 238; Halliday \& Matthiessen, 2004: 257) has helped the researcher to qualify $\boldsymbol{n 0 s} 63,72$ and 224 (Text1); $\boldsymbol{n 0 s} 183$ and 332.1 (Text2), $\boldsymbol{n} 0 \mathbf{s}$ 201.1 and 209 (Text3) as ERPs while n0s 73 and 79 (Text1), no 39.1.5 (Text 2) and n0s 50, 190, 215 and 219 (Text3) are taken as CRPs. This means that of the 14 there-introduced clauses, 50\% are existential as they ordinarily are and $\mathbf{5 0 \%}$ are circumstantial and thus introduce strange characters: the leopard, the faceless woman, dark forest.

As for the fewness of desiderative processes, coupled with that of transitive material ones, it shows that most characters, with the exception of Adu, have little power over their dreams. Indeed, those characters -Birago, Yaa and Nimo- who are overpowered in dreams by a leopard or a faceless woman who turns into aunt Goma (T2: 233-265; T3: 23-32), have been killed either by a storm-caused treefall or drowned by a running river. The contribution of nature is justified by the occurrence of meteorological processes (04.46\%) in which such elements as the wind, the river and thunder are manipulated through witchcraft to destroy nonbelievers. On the other hand, anytime Adu is attacked by a leopard in a dream (T1: 64-127, T3: 6-65), a pastor called Yaro (T1: 205-332) appears to pray or rescue him out (T3: 43-47; 209-236). Yet, Nimo is devoured in a dream for trying to rescue Adu from a leopard attack and then gets drowned by trying to save the boy from drowning (p. 85). This projection of spiritual failures/victories into 'real life' ones helps not only to claim that the characters' spiritual life precedes the physical one, but also to deduce that that the underlying ideology is that 'in the spiritual battle between the powers of darkness and the power of light, only those in Christ overcome' (1 John 4:4).

\section{CONCLUSiON}

This paper has purposed to study the stream-of-consciousness mode to find out its experiential features and to deduce the facets of focalisation and the ideology in a Ghanaian novel. The application an appropriated Process-taxonomy (Halliday \& Matthiessen, 2004: 208-210) has helped the analyst to discover that though material, relational and verbal clauses occur in significant proportions, most of them are contained within the group of 'mental + behavioural' classes which holds the lion's share in process distribution. As this group is more related to focalisation, the proportions of its sub-classes (behavioural, perceptive, cognitive, emotive, and desiderative) have helped to deduce that though the psychological (26.62\%) and the perceptual (22.47\%) facets overrate the ideological one $(04.14 \%)$, it is the least, added to the modality values of the estrangers and other mental processes, that has most 
Facets of Focalisation and Ideology in the Stream-of Consciousness Mode: A Study of Lawrence Darmani's Grief Child.

helped to determine the underlying ideology of the text. In a nutshell life is first spiritual before being physical as the characters' victories/failures in dreams are translated into victories/failures in real life.

\section{REFERENCES}

[1] Amoussou, C. Y. (2017). 'Linguistic Features of Internally-Focalized Discourse in Ngũgĩ wa Thiong'o's Matigari,' The Mediterranean Journal of Social Sciences, ISSN 2039-2117/ 2039-9349, Vol. 8, n ${ }^{\circ} 1$, pp. 224-264, Jan. 2017; Rome, Italy.

[2] Amoussou, C. Y. (2016). 'Lexico-grammatical features of the Second-Person in Ngũgĩ wa Thiong'o's First two Novels', PARTICIP'ACTION, Vol. 8, n 1 , Janvier 2016 ; pp. 243-261; Lomé: Togo.

[3] Amoussou, C. Y. (2014). "Transitivity Analysis of Two Stretches of Narrated Mental Discourse from Ngũgĩ's Wizard of the Crow," Revue du CAMES, nov.2014, Ouagadougou; pp.121-137.

[4] Baldick, Ch. (2009) (ed.) Oxford Dictionary of Literary Terms. Oxford: Oxford U.P.

[5] Banfield, A. (1981). 'Reflective and non-reflective conscience in the language of fiction', Poetics Today, 2, 2, 61-76.

[6] Barthes, R. (1975) 'An Introduction to the Structural Analysis of Narrative', NLH 6: 272-92.

[7] Brumfit, C. J. \&Carter R.A. (1991). Literature and Language Teaching. Oxford: Oxford University Press.

[8] Childs, P. \& Fowler, R. (2006). The Routledge Dictionary of Literary Terms. London \& New York: Routledge, Taylor \& Francis Group.

[9] Cohn, D. (1966). "Narrated Monologue: Definition of a Fictional Style," Comparative Literature, XVIII (1966), 97-112.

[10] Cohn, D. (1978).Transparent Minds: Narrative Modes for Presenting Consciousness in Fiction, Princeton, NJ: Princeton University Press.

[11] Cuddon, J. A. (1984). A Dictionary of Literary Terms. Harmondsworth, Penguin Books.

[12] Culler, J. (1975). Structuralist Poetics: Structuralism, Linguistics and the Study of Literature. London: Routledge \& Kegan Paul.

[13] Darmani, L. (1991). Grief Child. Lion Publishing. ISBN 978-0-7459-1821-1.

[14] Eggins, S. (1994): An Introduction to Systemic-Functional Linguistics. London: Pinter Publishers Ltd.

[15] Fontaine, L. (2013). Analysing English Grammar: A Systemic Functional Introduction. New York: Cambridge University Press.

[16] Friedman, M. (1955). Stream of Consciousness: A Study in Literary Method. New Haven: Yale University Press.

[17] Fowler, R. (1986). Linguistic Criticism. Oxford: Oxford University Press.

[18] Genette, G. (1980). Narrative Discourse. Ithaca, New York: Cornell University Press.

[19] Halliday, M. A. K. \& Matthiessen, Ch. (2004). An Introduction to Functional Grammar (3rd ed.) London: Hodder Headline Group.

[20] Halliday, M. A. K. \& Matthiessen, Ch. (2006). Construing Experience through Meaning: A Languagebased Approach to Cognition. London, New York: Continuum.

[21] Humphrey R. (1972). Stream of Consciousness in the Modern Novel. Berkeley \& Los Angeles: University of California Press.

[22] Jakobson, R. (1960). “Concluding Remarks: Linguistics and Poetics,” in Sebeok, T.

[23] (1960).Style in Language. Cambridge, Massachussetts: MIT Press.

[24] James, W. (1890). The Principles of Psychology. New York: Henry \& Company.

[25] Littlewood, W. T. (1976). 'Literary and Informational Texts in Language Teaching.' Praxis1: 19-26.

[26] Matthiessen, C.M.I.M. (1995). Lexicogrammatical Cartography: English Systems. Tokyo: International Language Science Publishers.

[27] Matthiessen, C.M.I.M. (1998). 'Construing Processes of Consciousness: from the Commonsense Model to the Uncommonsense Model of Cognitive Science.' In Martin, J.R., Veel, R. (eds). Reading Science: Critical and Functional Perspectives on Discourses of Science. London: Routledge, pp. 327-57.

[28] Murfin, R. and Ray, S. M. (2003). The Bedford Glossary of Critical and Literary Terms (2nd ed.). Bedford: St. Martin's.

[29] Uspensky, B. (1970, trs 1973). A Poetics of Composition: The Structure of the Artistic Text and Typology of Compositional Form. Berkeley: University of California Press.

[30] Stanzel, F. K. (1971). Narrative Situations in the Novel. Bloomington: Indiana U. P. 
Facets of Focalisation and Ideology in the Stream-of Consciousness Mode: A Study of Lawrence Darmani's Grief Child.

[31] Stanzel, F. K. (1981). 'Teller-characters and reflector characters in narrative theory,' Poetics Today, 2, 2, 5-16.

[32] Stevenson, R. (1992). Modernist Fiction: An Introduction. Lexington: Kentucky U.P.

[33] Widdowson, H. G. (1975). Stylistics and the Teaching of Literature. London: Longman.

\section{Appendix: 3.1. Process-Type Identification in the Texts}

3.1 1. Text 1: $[1 \ldots \ldots \ldots .57]^{(58)}$ [The stories of Susa haunted ${ }^{(\text {MeP-C)}}$ his young mind]. ${ }^{(59)}[$ He was moving away ${ }^{(M M P)}$ from the village ${ }^{(60)}$ [as if compelled ${ }^{(M e P-P)}$ by a force beyond his strength]. ${ }^{(61)}\left[\mathrm{He}\right.$ was ${ }^{(\boldsymbol{C R P})}$ in the forest, all alone]. ${ }^{\left({ }^{2}\right)}\left[\right.$ He looked around $\left.{ }^{(B P)}\right],{ }^{(63)}\left[\right.$ but there was ${ }^{(E R P)}$ no one $] .{ }^{(64)}\left[{ }^{(64.1)}\right.$ 'How did he come to be here?' ${ }^{\text {(MeP- }}$

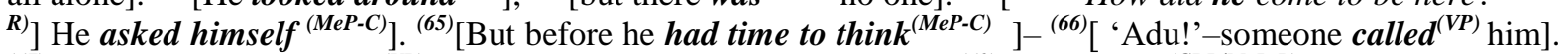
${ }^{(67)}$ [The voice was coming ${ }^{(V P)}$ from that wawa tree in front of him]. ${ }^{\left({ }^{(68)}\right)}$ [It sounded ${ }^{(C R P / M e P-P)}$ like the voice of a woman]. ${ }^{(69)}\left[\right.$ Fear overwhelmed ${ }^{(\text {MeP-E) }}$ him]. to become ${ }^{(I R P / M e P-P)}$ the ${ }^{(70)}\left[{ }^{(' A d u ! '-t h e ~ v o i c e ~}\right.$ came $^{(V P)}$ again]. ${ }^{(71)}[\mathrm{He}$ looked ${ }^{(B P)}$ behind him]; ${ }^{(72)}$ [there was $^{(E R P)}$ no one]. ${ }^{(73)}\left[\right.$ Suddenly there arose ${ }^{(C R P)}$ from behind the wawa tree] ${ }^{(74)}$ [what at first seemed ${ }^{(\text {CRP/MeP-P) }}$ like a dark winding smoke curling up the tree]. ${ }^{(75)}$ [Then it seemed figure of a long, thin human being peering down at him]. ${ }^{(76)}\left[\mathrm{A}\right.$ deep voice $\boldsymbol{e c h o e d}{ }^{(\boldsymbol{B P})}$ his own voice]. ${ }^{(77)}\left[\mathrm{He} \boldsymbol{h e a r d}^{\left(\boldsymbol{M e P}_{-1)}\right)}\right.$ a rustle behind him] ${ }^{(78)}$ [and turned ${ }^{(B P)}$ to see]. ${ }^{(79)}$ [There, strong and alert, stood ${ }^{(C R P)}$ a giant leopard]. ${ }^{(80)}$ [The animal snarled at $\left.{ }^{(\boldsymbol{B P})} \mathrm{him}\right] .{ }^{\left({ }^{(8)}\right.}\left[\mathrm{Her}\right.$ red eyes scrutinized $\left.{ }^{(\boldsymbol{M e P}-\boldsymbol{C})} \mathrm{Adu}\right] .{ }^{(82)}\left[\right.$ When she began to wag ${ }^{(\boldsymbol{B P})}$ her tail]

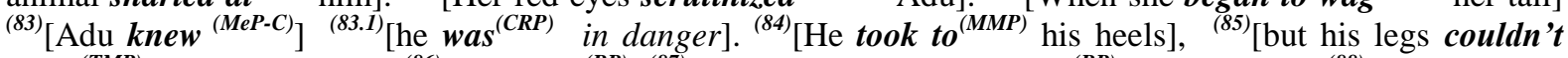
carry $^{(\text {(TMP) }}$ him fast enough]. ${ }^{\left({ }^{86}\right)}\left[\mathrm{He}_{\text {yelled }}{ }^{(\boldsymbol{B P})}\right]^{(87)}\left[\right.$ but his own voice bounced ${ }^{(\boldsymbol{B P})}$ back to him]. ${ }^{(88)}$ [The echo this

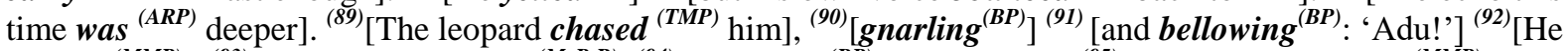
stopped $\left.^{\left(M_{M P}\right)}\right] .{ }^{(93)}\left[{ }^{(' W h o ~ c a l l e d ~ h i m ? '] ~}\right]^{(M e P-R)}{ }^{(94)}\left[\right.$ He turned $^{(B P)}$ round to see]. ${ }^{\left({ }^{(95)}\right.}$ [The leopard stopped ${ }^{(\text {MMP })}$, too], ${ }^{(96)}$ [and began wagging ${ }^{(B P)}$ her tail]. ${ }^{(97)}$ [Adu was about to take to ${ }^{(M M P)}$ his heels again] ${ }^{(98)}$ [when the animal crouched $\left.{ }^{(B P)}\right]{ }^{(99)}\left[\right.$ and sprang ${ }^{(M M P)}$ at him]. ${ }^{(100)}\left[\right.$ Adu cried out $\left.{ }^{(B P)}\right]{ }^{(101)}\left[\right.$ and dived ${ }^{(M M P)}$ to the side of the path].

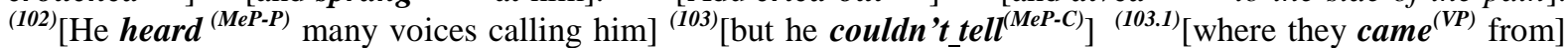
${ }^{(103.2)}$ [or whose they were ${ }^{\left({ }^{(P R P)}\right.}$ ]. ${ }^{(104)}$ [As he swung away ${ }^{(M M P)}$ from the path] ${ }^{(105)}$ [the huge animal missed ${ }^{(\text {TMP) }}$ him] ${ }^{(106)}$ [and fell $^{\left({ }^{(M M P)}\right)}$ heavily]. ${ }^{(107)}\left[\text { She rose } \text { up }^{(\boldsymbol{B P P})}\right]^{(108)}$ [and chased at ${ }^{(\text {(MPP) }}$ Adu] ${ }^{(109)}$ [as he ran ${ }^{(\text {MMP })}$ through the forest of Susa]. ${ }^{(110)}[\text { Did he not love plants, the trees and the birds? }]^{(\mathrm{MeP}-\mathrm{R})(111)}[$ Why had they now deserted him?] ${ }^{(\boldsymbol{M e P}-\boldsymbol{R})(112)}\left[\right.$ For they were ${ }^{(\boldsymbol{C R P})}$ now on the side of the pursuing animal]. ${ }^{(113)}\left[\right.$ They got ${ }^{(\boldsymbol{C R P})}$ in his way] ${ }^{(114)}$ [and hampered ${ }^{(\text {TMP) }}$ his progress]. ${ }^{(115)}\left[\right.$ Susa slept ${ }^{(B P)}$ on], ${ }^{(116)}$ [while one of the sons of the village struggled $^{(M M P)}$ alone in the forest with a beast] ${ }^{(116.1)}\left[\right.$ that was_determinate ${ }^{(\text {MeP-D) }}$ to destroy him]...... $[117 \ldots \ldots . . .285]{ }^{(286)}\left[\right.$ Y Yaro remembered ${ }^{(\mathbf{M e P})}$ the story of the corn and the weeds]: ${ }^{(286.1)}$ [Once a farmer planted $^{(\text {TMP) }}$ corn]. ${ }^{(286.2)}$ [In the night some worthless people went $\left.^{(\text {MMP })}\right]^{(286.3)}\left[\right.$ and planted ${ }^{(\text {TMP) }}$ weeds among them]. ${ }^{(286.4)}$ [When the corn germinated $\left.^{(A R P)}\right],{ }^{(286.5)}\left[\right.$ so did $^{(A R P)}$ the weeds]. ${ }^{(287)}$ ['What did the farmer you?' Yaro remembered_asking ${ }^{(M P P-C)}$ his missionary friend]. ${ }^{(288)}$ ['What would you do, if it were you?' the missionary threw back the question ${ }^{(V P)}$ to him in usual fashion]. ${ }^{(289)}$ ['Easy,' Yaro answered ${ }^{(V P)}$, 'just uproot the weeds and leave the corn].' (290) [But the farmer in the story didn't do ${ }^{(\text {TMP) }}$ that]. ${ }^{(291)}$ [Instead, he instructed ${ }^{(V P)}$ his laborers to allow the weeds and the corn to grow together], ${ }^{(292)}$ [for fear that if the laborers attempted to uproot ${ }^{(T M P)}$ the weeds] ${ }^{(293)}$ [they might uproot ${ }^{(\boldsymbol{T M P})}$ the corn as well]. ${ }^{(294)}$ ['Their fruits,' the missionary told ${ }^{\left(\boldsymbol{V P}^{\prime}\right)}$ him, 'would determine their fate].' ${ }^{(295)}$ [Although the missionary $\operatorname{told}^{(\boldsymbol{V P})}$ him] ${ }^{(295.1)}$ [that the lesson of the story was $^{(\text {IRP) }}$ ] ${ }^{(295.1 .1)}$ [that wicked men would eventually be cast away ${ }^{(\text {TMP })}$ ], ${ }^{(296)}$ [Yaro applied ${ }^{(M e P-D)}$ the story in his own way]: ${ }^{(296.1)}$ [if you mix $^{(T M P)}$ bad things with good ones in your life], ${ }^{(296.2)}$ [the good things will reward $^{(T M P)}$ you] ${ }^{(296.3)}\left[\right.$ but so will $^{(T M P)}$ the bad ones]. $[297 \ldots \ldots \ldots . . .324 .1]^{(325)}\left[\right.$ The boy had an ear for ${ }^{(B P)}$ God's word $]{ }^{\left({ }^{(326)}\right.}[\mathrm{He}$ did not shy away $\left.{ }^{(\text {MeP-E) }}\right]{ }^{(327)}$ [as some of his mates did $\left.^{(\text {MeP-E) }}\right]{ }^{(328)}\left[\right.$ whenever Yaro asked ${ }^{(\text {VP) }}$ them to accompany him to Buanyo or Dumasi to preach the word]. ${ }^{(329)}$ [Now Yaro thought ${ }_{-}^{(\text {MeP-C)}}$ about ${ }^{(329.1)}$ [what Nimo had told $^{\left(V_{P}\right)}$ him]: ${ }^{(329.2)}\left[\right.$ In the Bible when Joseph dreamt $\left.{ }^{(\boldsymbol{B P})}\right],{ }^{\left({ }^{(329.3)}\right.}\left[\right.$ the dream $\boldsymbol{h a d}^{\left({ }^{(P R P)}\right.}$ a bearing on his later life]. ${ }^{(329.4)}$ [Did Adu's dream have anything to do with his life?] ${ }^{\left(\text {MeP-R) }{ }^{(329.5)}\right.}$ [If so, what was the meaning of a leopard chasing a boy through a dark jungle?] ${ }^{(\text {MeP-R) (330) }}\left[{ }^{[S y m p a t h y ~ f i l l e d ~}{ }^{\left(\text {MeP-E) }^{2}\right.}\right.$ his heart]: ${ }^{(331)}[$ God, protect that life;

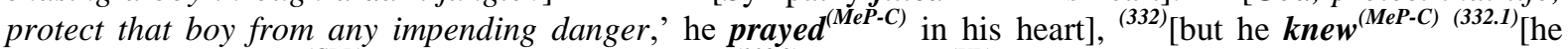
would have to spend ${ }^{(\boldsymbol{C R P})}$ more time with the boy] ${ }^{(332.2)}\left[\right.$ and teach $^{(V P)}$ him more about sustaining faith] (pp.919).

3.1.2. Text $2:[1 \ldots \ldots \ldots . .38 .1]^{(39)} *$ [Birago remembered $^{(\text {MeP-C)}}$ a legend] ${ }^{(39.1)} *$ [she had often told ${ }^{(V P)}$ children]: ${ }^{(39.1 .1)}$ [God used to be ${ }^{(\text {CRP })}$ very close to earth, so close that], ${ }^{(39.1 .2)}\left[\right.$ any time women prepared ${ }^{(\text {TMP })}$ food], ${ }^{(39.1 .3)}$ [ all ${ }^{(39.1 .3 .1)}$ [she needed ${ }^{(\text {MeP-D) }}$ for meat] was ${ }^{(I R P)}$ to cut a piece of the clouds] ${ }^{(39.1 .4)}$ [which was $^{(\text {IRP })}$ meat] and prepare food with it]. ${ }^{(39.1 .5)}$ [But there came $^{(\text {CRP) }}$ a time] ${ }^{(39.1 .6)}$ [when the people complained ${ }^{(B P)}$ ] (39.1.7) ${ }^{\text {[that the clouds were }}{ }^{(M T P)}$ too close], ${ }^{(39.1 .8)}$ [and hindered ${ }^{(M T P)}$ the smooth pounding to their fufu]. ${ }^{(39.1 .9)}$ [They complained ${ }^{(B P)}$ so bitterly] ${ }^{(39.1 .10)}$ [ that God went away ${ }^{(M M P)}$ from them]; ${ }^{(39.1 .11)}$ [hence the clouds were ${ }^{\left({ }_{M T P}\right)}$ now so far away in the sky]. ${ }^{(40)}$ Birago pulled ${ }^{(\boldsymbol{T M P})}$ her cover cloth over her body]. ${ }^{(41)}$ [When she had the

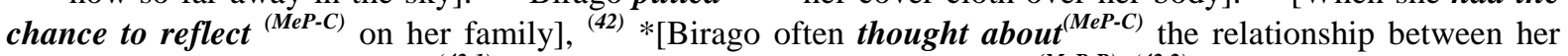
husband and Goma his sister]: ${ }^{(42.1)}$ [What could possibly be done to right] ${ }^{(\text {MeP-R) }}{ }^{(42.2)}$ [whatever wrong had been committed? $]^{(\text {MeP-R) (42.3) }}$ [To make matters worse, her husband often tried to hide the problem from her] ${ }^{(\text {MeP-R)}}$. 
Facets of Focalisation and Ideology in the Stream-of Consciousness Mode: A Study of Lawrence Darmani's Grief Child.

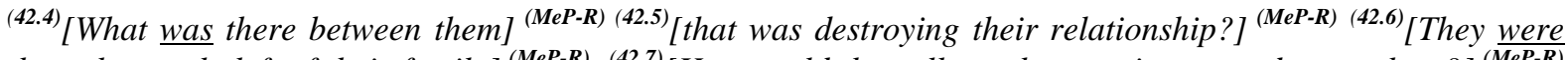
the only people left of their family] ${ }^{(\mathrm{MeP}-\mathrm{R})} .^{(42.7)}\left[\mathrm{How}\right.$ could they allow whatever it was to destroy them?] ${ }^{(\overline{M e P-R})}$ ${ }^{(43)}$ [Yet she felt sympathetic ${ }^{(\boldsymbol{M e P}-\boldsymbol{E})}$ towards Goma and towards her husband too]. ${ }^{(44)} *$ [Birago's thought turned to ${ }^{(M e P-C)}$ the rains]: ${ }^{(44.1)}$ [this season they had been ${ }^{(M T P)}$ heavy and long]. ${ }^{(44.2)}$ [In the afternoon she had been ${ }^{(M M P)}$ to the rice farm for some vegetables].* ${ }^{(44.3)}\left[\right.$ She didn't like ${ }^{(\text {MeP-E) }}$ the way] ${ }^{(44.3 .1)}$ [Swampy land was saturated $^{(M T P)}$ with brown water]. ${ }^{(44.3 .2)}$ [The small river ${ }^{\frac{144.3 .2 .1)}{2}}$ they had to cross $^{(M M P)}$ to get to their farm] was running $^{(M T P)}$ high, very close to the log-bridge]. ${ }^{\text {(44.3.3) }}$ [Too much rain could kill ${ }^{(\text {TMP) }}$ the maize], (44.3.4) [revive $^{(T M P)}$ the weeds], ${ }^{(44.3 .5)}$ [and make ${ }^{(A R P)}$ normal every life difficult and irritating]. ${ }^{(44.5)}$ [But you did not complain $^{(B P)}$-only in your thoughts!] $[45 \ldots \ldots \ldots .232]{ }^{(233)}[$ Then gradually her mind began to sort itself out $^{\left({ }^{(M P P-C)}\right] . ~}{ }^{(234)}\left[\right.$ First she remembered ${ }^{(\text {MeP-C)}}$ Yaa's sleep-talk the night before]. ${ }^{(235)}\left[\mathrm{Oh}\right.$, she thought ${ }^{\text {MeP-C })}$ ]: ${ }^{(235.1)}\left[\right.$ it was useless to ask her ${ }^{(\mathrm{MeP}-\mathrm{R}) ;}{ }^{(235.2)}\left[\right.$ Even if she were to ask her about it ${ }^{(\mathrm{MeP}-\mathrm{R})}{ }^{(235.3)}\left[{ }^{\text {she }} \mathbf{k n e w}^{(\mathrm{MeP}-\mathrm{C})}\right.$ instinctively ${ }^{(235.3 .1)}\left[\text { that Yaa would not remember }{ }^{(\text {MeP-C)}} \text { a thing }\right]^{(\text {MeP-R) }}{ }^{(236)}\left[\right.$ Birago was about to give up $\left.{ }^{(\text {MeP-C })}\right]$ ${ }^{(237)}$ [when she remembered ${ }^{(\text {MeP-C)}}$ something else]. ${ }^{(238)} *\left[\right.$ She had had ${ }^{(B P)}$ a dream]. ${ }^{(239)}$ [She had tried in vain to

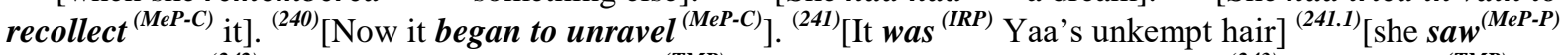
in the dream]. ${ }^{(242)}$ [Someone was trying to pull ${ }^{(\text {TMP) }}$ the girl's hair - no, hands, at first]. ${ }^{(243)}$ [She pulled ${ }^{(\text {TMP) }}$ her daughter to herself] ${ }^{(244)}$ [and tried to shield ${ }^{(\text {TMP) }}$ her from the intruder]. ${ }^{(245)}$ [At first it seemed ${ }^{(\text {CRP) }}$ like a play], ${ }^{(246)}$ [but the woman ${ }^{(246.1)}$ [whose face Birago couldn't quite remember ${ }^{(M e P-C)}$ now], became ${ }^{(A R P)}$ serious] ${ }^{(247)}$ [and reached out ${ }^{(\text {MMP) }}$ violently for the girl's hair]. ${ }^{(248)}$ [Yaa had screamed ${ }^{(B P)}$ ]. ${ }^{(249)}$ [The faceless woman let go ${ }_{-}^{(T M P)}$ the girl's hair ${ }^{(250)}$ [but, to Birago's astonishment, she had plucked off ${ }^{(\text {TMP) }}$ a handful already]. ${ }^{(251)}$ [From where she sat $\left.^{(\mathbf{B P})}\right]{ }^{(252)}\left[\right.$ Birago pictured ${ }^{(\text {MeP-C)}}$ Yaa's disheveled hair $] .{ }^{(253)}\left[\right.$ But before long she was picturing ${ }^{(\text {MeP-C)}}$ Yaa's hair in the hands of the faceless woman]. ${ }^{(254)}$ [Now the woman moved ${ }^{(M M P)}$ towards Birago herself]. ${ }^{(255)}$ [The dream was ${ }^{(A R P)}$ vivid]. ${ }^{(256)}\left[\right.$ As she sat remembering ${ }^{(\text {MeP-C)}]}$, ${ }^{(257)}\left[\right.$ Birago's eyes shifted ${ }^{(B P)}$ from her daughter's hair] ${ }^{(258)}$ [ and were now fixed ${ }^{(B P)}$ sightlessly on the entrance to the house]. ${ }^{(259)}$ [In her mind she could see $^{(\text {MeP-P) }}$ herself $]^{(259.1)}\left[\right.$ struggling to run $^{(\text {MMP) }}$ from the faceless one ${ }^{(260)}$ [but the woman overpowered ${ }^{(\text {TMP })}$ her]. ${ }^{(261)}$ [The woman had shot ${ }^{\text {(TMP) }}$ her hands straight into Birago's hair] ${ }^{(262)}$ [and before she could give ${ }^{(\text {TMP) }}$ the assailant a slap $]^{(263)}$ [she was gone ${ }^{(\mathbf{M M P})}$ with hair in each hand toward the gate]. [264.......... 316] [Her mother had interrupted $^{(\text {MeP-D)}}$ her thoughts]. ${ }^{(317)}$ [She was thinking ${ }^{(\text {MeP-C)}}$ about the incident at home]. ${ }^{(318)}$ [Why had her mother screamed the way she did?] ${ }^{(M e P-R)(319)}$ [That scream, to her best remembrance, had a streak of fear in it ${ }^{(\mathbf{M e P}-\mathrm{R})},{ }^{(320)} \quad$ [yet she had never seen or heard her mother show fear] ${ }^{(\mathbf{M} P-\boldsymbol{R})}{ }^{(321)}$ [And her scream had

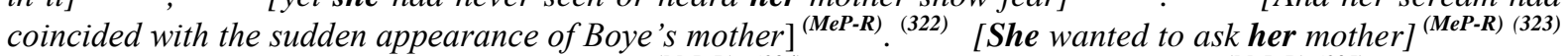
[why she had screamed on seeing her friend] ${ }^{(\mathrm{MeP}-\mathrm{R})} .^{\left({ }^{(324)}\right.} \quad$ [Was anything the matter?] ${ }^{(\mathrm{M} e \mathrm{P}-\mathrm{R})(325)}$ [Unknown to Yaa, Birago was $_{\text {occupied }}{ }^{(\text {MeP-C)}}$ with her own thoughts]. ${ }^{(326)}$ [And they were $^{(\text {CRP) }}$ about Yaa]. ${ }^{(327)}$ [She tried to reconcile $^{(\text {MeP-C)}}$ her dream], ${ }^{(328)}$ [which she recalled ${ }^{(M e P-C)}$ now, with Yaa's sleep-talk]. ${ }^{(329)}$ [Who did Yaa see in

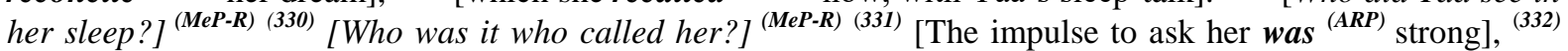
[but she Knew $\left.^{(\text {MeP-C)}}\right]^{(332.1)}$ [there was ${ }^{(E R P)}$ no way] ${ }^{(332.2)}$ [Yaa could remember ${ }^{(\text {MeP-C)}}$ ]. ${ }^{(333)}$ [It was only sleeptalk $^{(\text {MeP-R) }}{ }^{(334)}\left[\right.$ But on second thought she decided to try ${ }^{(\text {MeP-D)}}$ ]. (pp.61-69)

3.1.3. $\underline{T e x t}_{3:}{ }^{(1)}\left[\right.$ That night Adu had a nightmare $\left.{ }^{(B P)}\right] .{ }^{(2)}\left[\right.$ His spirit was broken $\left.{ }^{(\text {MeP-D)}}\right] .{ }^{(3)}\left[\mathrm{He}\right.$ felt ${ }^{(\text {MeP-P)}}$ the little light in him giving way to darkness]. ${ }^{(4)}$ [As he tossed about ${ }^{(\boldsymbol{B P})}$ in bed] ${ }^{(5)}\left[\right.$ he felt like giving up $^{(\mathbf{M e P}-\mathrm{D})}$ on life $]-{ }^{(5.1)}\left[\right.$ to say $^{(\boldsymbol{V P})}$ goodbye to this world] ${ }^{(5.2)}$ [and be gone ${ }^{(\boldsymbol{B P})}$ forever and ever]. ${ }^{(\boldsymbol{6})}\left[\mathrm{He}\right.$ drifted ${ }^{(\text {MeP-D)}}$ into darkness against his inner will], ${ }^{(7)}\left[\right.$ as if he was being pushed ${ }^{(T M P)}$ into a deep well full of many faces]. $\left({ }^{8)}[\right.$ The faces were ${ }^{(A R P)}$ weird $] .^{\left({ }^{(9)}\right.}\left[\mathrm{He} \text { saw }{ }^{(\text {MeP-P)}} \text { a pair of eyes }\right]^{(9.1)}\left[\right.$ staring at ${ }^{(B P)}$ him $] .{ }^{\left({ }^{(10)}\right.}\left[\mathrm{He}\right.$ thought $\left.{ }^{(\boldsymbol{M e P}-\boldsymbol{C})}\right]{ }^{(10.1)}[\mathrm{he}$ was about to recognize ${ }^{(\text {MeP-C)}}$ the face ${ }^{(11)}$ [when the strange eyes blinked ${ }^{(B P)}$ ]. ${ }^{(13)}$ [Now the face was no longer ${ }^{(A R P)}$ a human face]; ${ }^{(14)}$ [it was ${ }^{(I R P)}$ the face of a leopard]. ${ }^{(15)}$ [Cold fear surged ${ }^{(\text {MeP-E) }}$ into him] ${ }^{(16)}$ [as he was forced $^{(\text {MeP-E) }}$ by a power greater than himself ${ }^{(16.1)}\left[\text { to look at }{ }^{(B P)} \text { the very object }\right]^{(16.2)}\left[\right.$ that drove $\boldsymbol{e}^{(\text {MeP-E })}$ fear into him]. ${ }^{(17)}$ [The leopard now rose ${ }^{\left({ }_{M M P}\right)}$ from the deep well] ${ }^{(18)}\left[\right.$ and moved $^{(\text {MMP })}$ towards him $] .{ }^{(19)}$ [He screamed $\left.{ }_{(\boldsymbol{B P})}\right]^{(20)}$ [and turned ${ }^{(\mathbf{M M P})}$ towards his parents] ${ }^{(20.1)}$ [whom he saw ${ }^{(\mathbf{M e P}-\boldsymbol{P})}$ standing beside him]. ${ }^{(21)}$ [As the leopard approached $\left.^{(\text {MMP) }}\right],{ }^{(22)}\left[\right.$ everyone dispersed $\left.{ }^{(M M P)}\right] .{ }^{(23)}\left[\mathrm{He}\right.$ saw $\left.\left.^{(\text {MeP-P)}}\right]\right]^{(23.1)}\left[\right.$ the beast running after ${ }^{(\text {TMP })}$ his mother and his little sister]. ${ }^{(24)}\left[\mathrm{He}\right.$ himself held on ${ }^{(\boldsymbol{B P})}$ tightly to his father] ${ }^{(25)}$ [as they stood $^{(\boldsymbol{B P})}$ there helpless] ${ }^{(26)}$ [while the leopard tore ${ }^{(\text {TMP) }}$ them to pieces]. ${ }^{(27)}$ [His father rushed ${ }^{(\text {MMP) }}$ to rescue them], ${ }^{(28)}$ [but he was ${ }^{(\text {CRP) }}$ too late]. ${ }^{(29)}$ [Now the leopard turned $\left.{ }^{(\text {MMP) }}\right]^{(30)}$ [and ran after ${ }^{(\text {TMP) }}$ his father]. ${ }^{(31)}$ [Before his eyes the animal attacked $^{(\text {TMP) }}$ his father ${ }^{(32)}$ and conquered ${ }^{(\text {TMP })}$ him $] .{ }^{(33)}\left[\right.$ He screamed $\left.{ }^{(B P)}\right]{ }^{(34)}\left[\right.$ and took to ${ }^{(\text {MMP) }}$ his heels $] .{ }^{(35)}[$ He turned ${ }^{(M M P)}{ }^{(36)}\left[\left(\right.\right.$ in order) to se $\left.^{(\text {MeP-P)}}\right]{ }^{(36.1)}\left[\right.$ the devouring beast dashing after $^{(\text {TMP) }}$ him]. ${ }^{(37)}\left[\right.$ When he looked ${ }^{(B P)}$ ahead] ${ }^{\left({ }^{38}\right)}$ [he saw ${ }^{\left(M \overline{e P}^{-P)}\right)}$ his friend Yaro standing by]. ${ }^{\left({ }^{39}\right)}$ [Quickly he threw ${ }^{(\boldsymbol{B P})}$ himself upon his friend], ${ }^{(40)}\left[\right.$ panting $\left.{ }^{(B P)}\right]{ }^{(41)}\left[\right.$ and fainting $\left.{ }^{(B P)}\right] .{ }^{(42)}\left[\mathrm{He}\right.$ was sure ${ }^{\left({ }^{(M P P-C)}\right)}{ }^{(42.1)}\left[\right.$ the animal was going to get ${ }^{(T M P)}$ them both], ${ }^{(43)}$ [but to his surprise the beast stopped ${ }^{(\text {MMP) }}$ short], ${ }^{(44)}\left[\right.$ unable to approach ${ }^{(\text {MMP })}$ them]. ${ }^{(45)}$ [Something seemed to be shielding ${ }^{(\text {TMP) }}$ him and Yaro against the approaching force of the beast]. ${ }^{(46)}\left[\mathrm{He} \boldsymbol{s a w}^{(\text {MeP-P)(46.1)}[\text { the animal }}\right.$ spitting ${ }^{(\boldsymbol{B P})}$ fire] ${ }^{(47)}$ [while gazing at ${ }^{(\boldsymbol{B P})}$ them]. ${ }^{(48)}$ [Then, as he stared ${ }^{(\boldsymbol{B P})}$ into those fearful eyes], ${ }^{(49)}$ [the animal changed into ${ }^{(A R P)}$ a human being]. ${ }^{(50)}$ [There before him stood ${ }^{(\boldsymbol{C R P})}$ his aunt $] . . . . .[51 \ldots \ldots .236]{ }^{(237)}$ [A fish in the deep, dark water splashed after ${ }^{(T M P)}$ a worm] ${ }^{(238)}$ [and alerted ${ }^{(B P)}$ Adu]. ${ }^{(239)}$ [The same hatred ${ }^{(239.1)}$ [he had had $^{(\text {MeP-E)}}$ for his aunt] spilled over ${ }^{(\text {MeP-E)}}$ against his friend Yaro]. ${ }^{(240)}$ [Yaro had destroyed ${ }^{(\text {TMP) }}$ his plans]. 
Facets of Focalisation and Ideology in the Stream-of Consciousness Mode: A Study of Lawrence Darmani's Grief Child.

${ }^{(241)}\left[\right.$ For the first time anger burned ${ }^{(\text {MeP-E) }}$ in his heart against Yaro]. ${ }^{(242)}$ [It was he who had just told him he could not decide for himself that his work on earth was finished] ${ }^{(\text {MeP-R) }}$ (243) $^{(26 h a t ~ w a s ~ t h e r e ~ l e f t ~ f o r ~ h i m ~ t o ~ d o ?] ~}$ ${ }^{(\mathrm{MeP}-\mathrm{R})}{ }^{(244)}[\text { His father was dead }]^{(\mathrm{MeP}-\mathrm{R})}{ }^{(245)}\left[\mathrm{His}\right.$ mother was dead] ${ }^{(\mathrm{MeP}-\mathrm{R})}{ }^{(246)}[\mathrm{He}$ had no relative who cared for

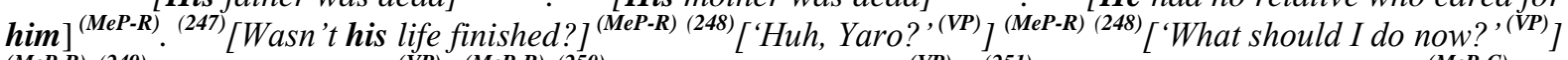
${ }_{(M e P-R)(249)}^{[}[\text {Tell me, Yaro!' (VP) }]^{(M e P-R)}{ }_{(250)}\left[\right.$ And the reply came $\left.{ }^{(V P)}\right],{ }^{(251)}\left[\right.$ though he neither expected $^{(M e P-C)}$ it] ${ }^{(252)}\left[\right.$ nor wanted ${ }^{(M e P-D)}$ it]: ${ }^{(250.1)}\left[{ }^{\prime} G o d\right.$ is able to change even the worst situation to something better]. ${ }^{(253)}[\mathrm{He}$ found himself ${ }^{(M e P-P)}$ in Yaro's room, after his mother's death]. ${ }^{(254)}{ }^{[T h o s e}$ were ${ }^{(I R P)}$ the very words] ${ }^{(254.1)}$ [Yaro had spoken ${ }^{(V P)}$ to him] ${ }^{(255)}$ [when his mother and sister $\operatorname{died}^{(\boldsymbol{B P})}$ ]. ${ }^{(256)}\left[\mathrm{It}\right.$ was $^{(\boldsymbol{C R P})}$ in the same season] ${ }^{(256.1)}[$ that his father was ${ }^{(\text {ARP) }}$ drowned]. ${ }^{(257)}$ [What did Yaro tell him about that?] ${ }^{(\text {MeP-R) }}{ }^{(258)}[$ He had told him that God had

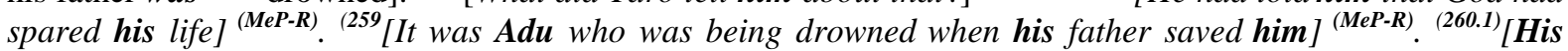
father had sacrificed his life for him $]^{(\mathbf{M e P}-\boldsymbol{R})},{ }^{(260)}\left[\right.$ Yaro $\left.\underline{\text { said }}^{(\boldsymbol{V P})}\right] . \quad[261 \ldots . .378]$ (pp.121-129)

Citation: Yémalo, C. AMOUSSOU. "Facets of Focalisation and Ideology in the Stream-of Consciousness Mode: A Study of Lawrence Darmani's Grief Child." International Journal of Humanities Social Sciences and Education (IJHSSE), vol 8, no. 8, 2021, pp. 66-80. doi: https://doi.org/10.20431/2349-0381.0808006.

Copyright: (c) 2021 Authors. This is an open-access article distributed under the terms of the Creative Commons Attribution License, which permits unrestricted use, distribution, and reproduction in any medium, provided the original author and source are credited. 